Article

\title{
Optimizing Quality of Wood Pellets Made of Hardwood Processing Residues
}

\author{
Evelyne Thiffault ${ }^{1, *} \mathbb{C}$, Julie Barrette ${ }^{2}$, Pierre Blanchet ${ }^{1,3}{ }^{-}$, Quy Nam Nguyen $^{1}$ and \\ Kokou Adjalle ${ }^{4}$
}

1 Centre de Recherche sur les Matériaux Renouvelables, Département des Sciences du bois et de la forêt, Université Laval, 2425 rue de la Terrasse, Pavillon Gene-H.-Kruger, Université Laval, Québec, QC G1V 0A6, Canada

2 Direction de la Recherche Forestière, Ministère des Forêts, de la Faune et des Parcs, 2700 Rue Einstein, Bureau B.1.145, Québec, QC G1P 3W8, Canada

3 Chaire Industrielle de Recherche du CRSNG sur la Construction écoresponsable en bois, 2425 rue de la Terrasse, Pavillon Gene-H.-Kruger, Université Laval, Québec, QC G1V 0A6, Canada

4 Centre Eau Terre Environnement, Institut National de la Recherche Scientifique, 490 Rue de la Couronne, Québec, QC G1K 9A9, Canada

* Correspondence: evelyne.thiffault@sbf.ulaval.ca; Tel.: +1-418-656-2131 (ext. 405405)

Received: 19 June 2019; Accepted: 19 July 2019; Published: 23 July 2019

check for updates

\begin{abstract}
Small-scale wood pellet producers often use a trial-and-error approach for determining adequate blending of available wood processing residues and pelletizing parameters. Developing general guidelines for optimizing wood pellet quality and meeting market standards would facilitate their market entry and profitability. Four types of hardwood residues, including green wood chips, dry shavings, and solid and engineered wood sawdust, were investigated to determine the optimum blends of feedstocks and pelletizing conditions to produce pellets with low friction force, high density and high mechanical strength. The feedstock properties reported in this study included particle size distribution, wood moisture content, bulk density, ash content, calorific values, hemicelluloses, lignin, cellulose, extractives, ash major and minor elements, and carbon, nitrogen, and sulfur. All residues tested could potentially be used for wood pellet production. However, high concentrations of metals, such as aluminum, could restrict their use for accessing markets for high-quality pellets. Feedstock moisture content and composition (controlled by the proportions of the various residue sources within blends) were the most important parameters that determined pellet quality, with pelletizing process parameters having less overall influence. Residue blends with a moisture content of $9 \%-13.5 \%$ (dry basis), composed of $25 \%-50 \%$ of sawdust generated by sawing of wood pieces and a portion of green chips generated by trimming of green wood, when combined with a compressive force of $2000 \mathrm{~N}$ or more during pelletizing, provided optimum results in terms of minimizing friction and increasing pellet density and mechanical strength. Developing formal relationships between the type of process that generates residues, the properties of residues hence generated, and the quality of wood pellets can contribute to optimize pellet production methods.
\end{abstract}

Keywords: wood processing residues; hardwoods; pellet production; residue characterization; pelletizing process parameters; moisture content

\section{Introduction}

Bioenergy (i.e., energy derived from biomass) is one of the most important renewable energy sources today. It is expected to play a major role for replacing fossil fuels in the global energy systems and for reducing greenhouse gas (GHG) emissions over the next decades [1]. By 2035, biomass could 
deliver 120 exajoules (EJ) (50\% of the world's energy needs) for heat, 15\% EJ for transport, and $18 \mathrm{EJ}$ (7\%) for electricity $[2,3]$.

In temperate and boreal countries, forest biomass, in the form of wood chips and wood pellets, is used for power and/or heat production, with boilers of various capacities ranging from small community heating systems up to large power plants. Relative to wood chips, pellets have a higher energy density per unit of mass and volume, are easier to store and handle in large volumes, and show less heterogeneity in physical and chemical properties [4,5]. Whereas wood chips are often preferred for small-scale facilities for which feedstock can be sourced over short distances, wood pellets can be used in larger-scale installations and/or for transport and trade over long distances (e.g., transatlantic and transpacific trade) [6].

In the province of Quebec (Canada), the primary and secondary wood processing sectors generate large amounts of wood residues annually. In 2013, the hardwood flooring industry generated about $400 \times 10^{3}$ metric tons of wood residues including sawdust, wood chips, and wood shavings [7]. A share of those residues is traded with other facilities for pulp and paper or fiberboard production; a portion is also used internally within facilities for heat or heat-and-power production [8]. However, the emergence of a larger market for bioenergy, especially for export, is driving interest into the characterization and quantification of these residues as potential feedstock for wood pellet production. Hardwood residues are generally considered less suitable for wood pellet production than softwood residues because of the greater friction generated during hardwood pelletization and lower mechanical durability of hardwood pellets. The high frictional forces in the channels of the die when hardwoods are used makes it more difficult to pelletize, potentially causing blockages at the pellet mill $[9,10]$. Nevertheless, studies suggest that with adequate conditioning and pelletizing conditions, hardwood residues can still be processed into pellets [11].

Quality requirements for wood pellets vary greatly depending on the end-user; as such, different wood pellet standards are being developed for various markets (e.g., Pellet Fuels Institute (PFI) standard, Austrian Standard International (ÖNORM) M 7135, International Organization for Standardization (ISO) 17225, German Institute for Standardization (DIN) 51731, etc.). The physical and chemical properties of the feedstocks largely define the characteristics of the wood pellets [12,13]. However, properties of residues that are generated by wood processing industries are poorly quantified. Uncertainty over the impacts of the variability in feedstock properties on the quality of wood pellets and the consequent impact of the ability of wood pellets to meet market standards are important hurdles to wood pellet market penetration [14,15]. Small-scale producers often use trial-and-error methods for determining adequate pelletizing parameters (i.e., temperature and compression force) and blending of available wood residues generated along their wood processing chains. Developing general guidelines for optimizing pellet quality, by predicting properties of residues as a function of the processes that generate them within production lines and choosing feedstock composition and pelletizing parameters for meeting standards, would facilitate market entry for new players.

The aim of this study was to develop relationships between characteristics of different kinds of residues generated along production chains of wood products and quality of wood pellets, to identify optimum feedstock and pelletizing conditions for pellet production. Wood residues from two production chains of hardwood flooring were used as a case study. The specific objectives were to: (i) characterize chemical and physical properties of wood residues as a function of their origin within the production chains of hardwood flooring, (ii) characterize blends of residues (mixing of residues of different origins), and (iii) investigate the combined effects of residue characteristics and pelletizing parameters on quality of wood pellets. 


\section{Materials and Methods}

\subsection{Sample Collection and Preparation}

In the autumn of 2015, four types of wood residues were collected from a flooring manufacturer in eastern Canada. These residues included green wood chips obtained from the wood chipper based in the courtyard of the flooring manufacturer, dry shavings and sawdust from solid hardwood flooring, and dry sawdust from engineered wood flooring. The production lines for the two types of flooring are presented in Figure 1, with indications of the sources of residues.

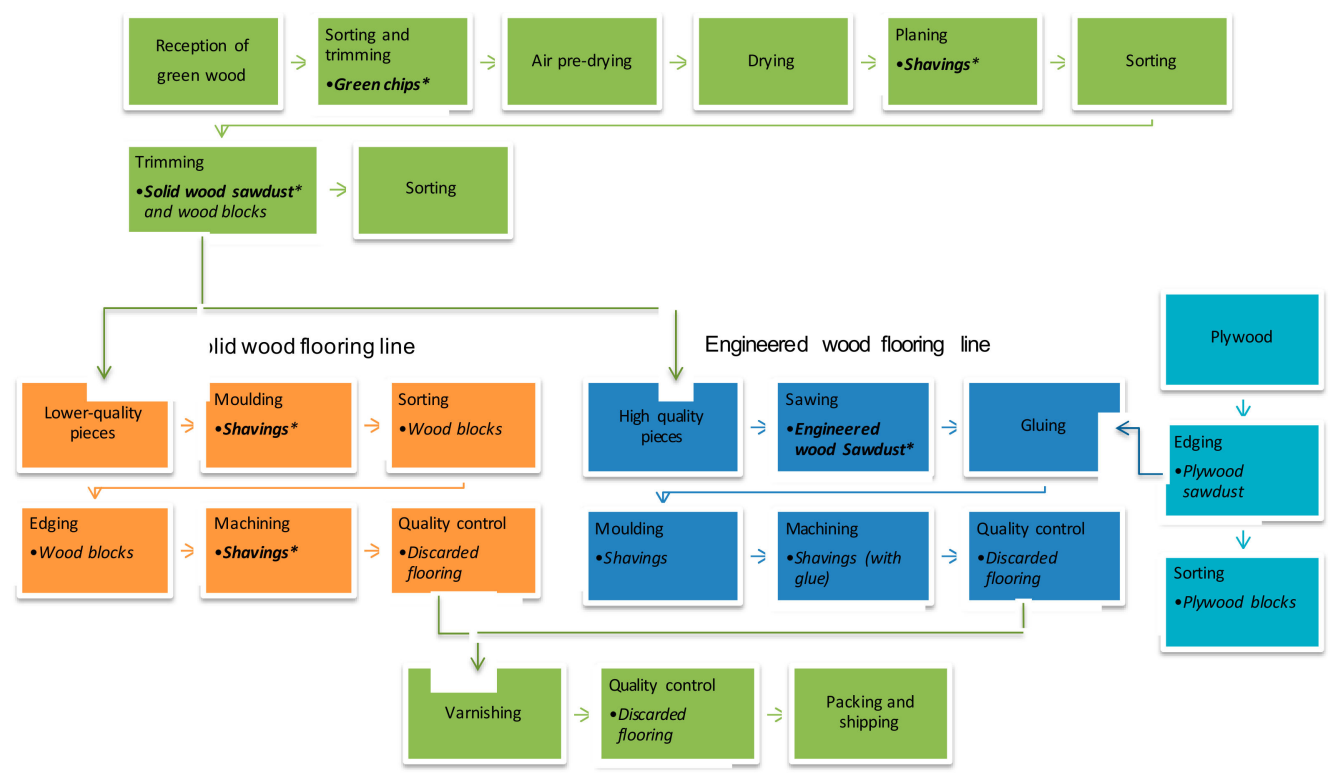

Figure 1. Production lines for the solid and engineered wood flooring. Residues from each process are indicated in italics. Residues collected for pelletizing are indicated with *.

Four samples of about $0.2 \mathrm{~m}^{3}$ of each type of wood residue were collected separately within the facilities of the manufacturer. The selected samples were kept in sealed 55 US gallon (208 L) drums and transported to the laboratory, where they were kept in a laboratory freezer at $-4{ }^{\circ} \mathrm{C}$ to avoid moisture loss and wood degradation.

Laboratory samples (approximately $1.5 \mathrm{~kg}$ each) of the four single residue sources/origins were analyzed for their chemical and physical properties. They were then used to prepare ten combinations of residue sources, which were used for pelletizing experiments and pellet quality assessments. The samples of mixed residues were prepared by blending different single residue sources in various proportions, as presented in Figure 2, until homogeneity was achieved prior to pelletizing. Proportions of residue sources within blends were selected to facilitate comparisons between residue sources; particle size and abundance of residues were also taken into account. First, blends containing either only dry shavings (Blend 1) or green chips (Blend 2) were made. No pure blends of either type of sawdust were made, since the very small size of their particles would have made the blends difficult to pelletize. Dry shavings, being the most abundant residue type, were mixed using three parts of shavings and one part of either solid wood (Blend 4) or engineered wood (Blend 5) sawdust. Other blends were made by mixing equal parts of two residue sources (Blends 3,6,7,8, and 9) or of all four residue sources (Blend 10).

From each of the ten different blends, three subsamples were created. Two subsamples were placed inside conditioning chambers under controlled air temperature and relative humidity conditions; two sets of conditions were tested-20 ${ }^{\circ} \mathrm{C}$ and $60 \%$, and $20{ }^{\circ} \mathrm{C}$ and $75 \%$ - corresponding to measured equilibrium moisture contents in the wood grinds of $12 \%$ and $15 \%$ on a dry basis, respectively. The remaining subsample was kept at its initial moisture content when the blend was formed and kept 
in a sealed plastic bag to avoid moisture loss. All blends were further tested for their physical and chemical properties.

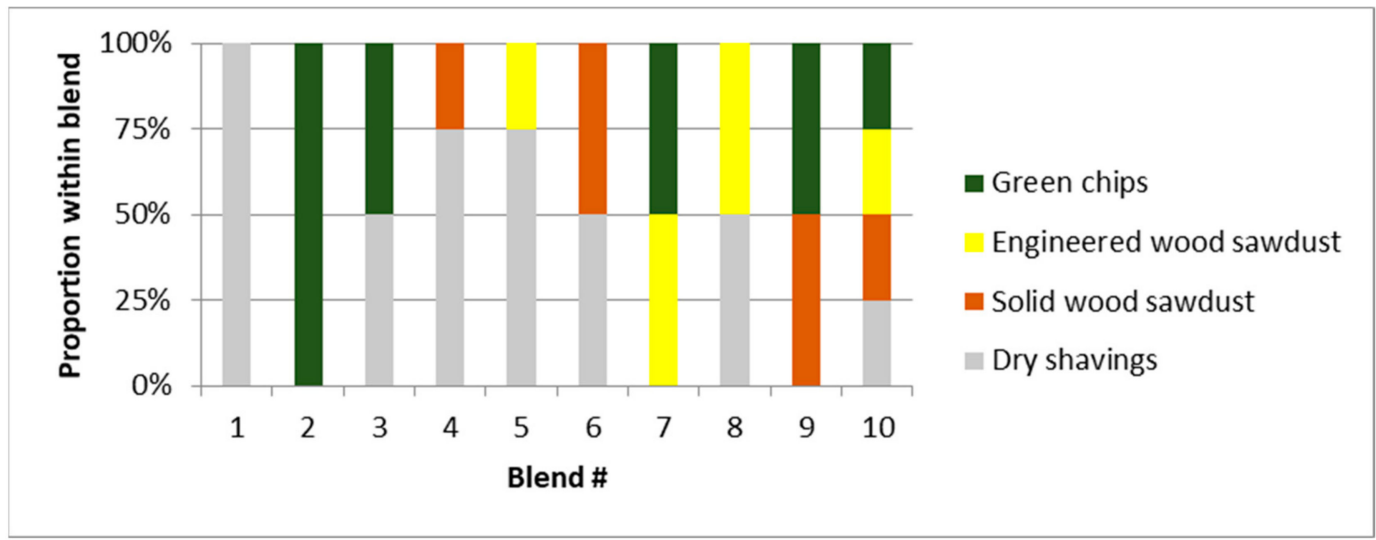

Figure 2. Proportion of sources of residues within blends (in \%).

\subsection{Characterization of Hardwood Flooring Residues}

Characterization of the four single residue sources (green wood chips, dry shavings, solid wood sawdust, and engineered wood sawdust) and the ten combinations of mixed residues was performed. For single residue sources, the following properties were determined: ash minor and major element concentrations; carbon (C), nitrogen (N), and sulfur (S) concentrations; and proportion of hemicelluloses, cellulose, lignin, and extractives. For both single residue sources and residue blends, the following properties were determined: particle size distribution, wood moisture content, bulk density, ash content, and calorific values.

Particle size distribution of coarse residues (i.e., green wood chips) and smaller size residues (i.e., shavings and sawdust) were determined in accordance with British Standards (BS) EN15149-1 [16] and BS EN15149-2 [17]. These standards recommend that the number of sieves and the aperture sizes of the sieves should be chosen according to the size specification of the sample material. In the current study, the particle size distributions of shavings and sawdust were analyzed using 3.85, 2.60, $1.50,1.00,0.50$, and $0.25 \mathrm{~mm}$ sieve sets, while the green wood chips used 45.0, 28.6, 22.2, 15.9, 9.5, and $4.8 \mathrm{~mm}$ sieve sets. More details about the determination of particle size distribution can be found in Nguyen et al. [11] and Barrette et al. [18]. The moisture content was determined in accordance with the EN ISO 18134-3:2015 standard [19]: a sample of about $5 \mathrm{~g}$ was dried in an oven at $105 \pm 2{ }^{\circ} \mathrm{C}$ for $24 \mathrm{~h}$. Bulk density was determined in accordance with American Society for Testing and Materials (ASTM) D5057-10 standards [20]. Chemical and thermal properties of all residues were then tested from sawdust of $0.25 \mathrm{~mm}$.

The higher heating value (HHV) was determined in accordance with BS EN14918:2009 standards [21], where the sample (approximately $0.7 \mathrm{~g}$ ) was compacted into a tablet and combusted in a Parr 6400 Automated Isoperibol calorimeter (Parr Instrument Company, Moline, Illinois, USA).

While not essential to the determination of wood pellet quality based on the ISO standard 17225-2, the proportions of cellulose, hemicelluloses, and lignin were still determined to investigate their links with other properties. They were determined using the global analysis method developed by Van Soest et al. [22] and recommended by Godin et al. [23]. These measurements were taken in order to better characterize the wood residues used for this experiment.

The elemental proportions of C, N, and S were analyzed using a Leco (CNS-2000, St. Joseph, Michigan, USA). About $100 \mathrm{mg}$ of wood powder was burned at $1350{ }^{\circ} \mathrm{C}$ (for about $2 \mathrm{~min}$ ) under an oxygen atmosphere. At this temperature, all forms of $\mathrm{C}, \mathrm{N}$, and $\mathrm{S}$ were oxidized in $\mathrm{CO}_{2}$, $\mathrm{SO}_{2}, \mathrm{~N}_{2}$, and $\mathrm{NO}_{\mathrm{x}}$. After humidity and ash elimination, the concentrations of $\mathrm{CO}_{2}$ and $\mathrm{SO}_{2}$ were determined by using an infrared detector, while $\mathrm{NO}_{2}$ and $\mathrm{NO}_{\mathrm{x}}$ were determined by thermal conductivity. Concentrations obtained were assumed to correspond to the total C, N, and S present in the sample. 
The ash content was determined in accordance with ASTM D1102-84 standards [24]. The porcelain crucible containing approximately $2.0 \mathrm{~g}$ was burnt in muffle furnace at $575 \pm 25^{\circ} \mathrm{C}$ for $6 \mathrm{~h}$.

Concentrations of minor ( $\mathrm{Cu}, \mathrm{Mn}$, and $\mathrm{Zn}$ ) and major $(\mathrm{Al}, \mathrm{Ca}, \mathrm{Fe}, \mathrm{K}, \mathrm{Mg}$, and $\mathrm{P}$ ) elements in ash were determined using inductively coupled plasma (ICP) atomic emission spectrometry (PerkinElmer Optima 7300 Waltham, Massachusetts, USA). Again, although those elements are not strictly regulated for pellet quality, they could give important insights about potential sources of contamination during the generation of residues. About $500 \mathrm{mg}$ of wood powder was burned at $500{ }^{\circ} \mathrm{C}$ for $2 \mathrm{~h}$ in porcelain crucibles. The remaining ashes were then mixed with $10 \mathrm{~mL}$ of chloric acid $(1 \mathrm{M})$ and heated for $20 \mathrm{~min}$. This allowed ash dissolution in the acid. Mixes were later transferred into $100 \mathrm{~mL}$ flasks. After $24 \mathrm{~h}$, ashes were deposited, and the liquid from the flask was transferred for analysis for minor and major elements using ICP spectroscopy.

\subsection{Pellet Production and Characterization}

A Pallmann ring refiner (Type PSKM 8, Ludwig Pallmann K.G., Zweibrücken, Germany) was used to convert the green wood chips and the dry shavings into ground material with suitable sizes for pellet production. Refiner screen sizes of 3.0 and $4.0 \mathrm{~mm}$ were used for size reductions of green wood chips and shavings, respectively.

The experimental plan was designed to test the pelletization characteristics of ten different mixes of residues (blends) under 12 controlled conditions that represented combinations of feedstock moisture content (as is, $12 \%$, and $15 \%$ ), pelletizing temperature $\left(100\right.$ and $\left.125{ }^{\circ} \mathrm{C}\right)$ and compressive force (1500 and $2500 \mathrm{~N}$ ), with a total of 120 independent experiments (or runs). The pelletizing temperatures as well as the compressive forces chosen for this experiment were based on a previous study [11]. Each run was replicated six times. Three dependent variables including friction force, pellet density, and pellet strength were measured. A total of 720 pellets were individually produced in a single pelletizer. Details about the single pelletizer used and the pellet production process can be found in Nguyen, Cloutier, Achim, and Stevanovic [11], but it is summarized here. The single pelletizer with a cylinder of $6.25 \mathrm{~mm}$ inner diameter and $150 \mathrm{~mm}$ long was first heated to the desired temperature. After equilibration, a sample of wood material of about $0.5 \mathrm{~g}$ was put into the cylinder and compressed by a piston at a speed of $12 \mathrm{~mm} \cdot \mathrm{min}^{-1}$ to the desired pressure. After a retention time of $10 \mathrm{~s}$ at full pressure, the pellet was pressed out of the cylinder by removing the bottom plate. The force-displacement data were recorded for the whole cycle of compaction and ejection of pellets. Data for friction were measured. Each pellet produced was stored in a sealed vial for further measurements.

The density of each single pellet was calculated by dividing its mass by its volume. The mass was measured by using an analytical balance with an accuracy of $\pm 0.0001 \mathrm{~g}$. The volume was calculated from the diameter and length of the pellet, assuming a perfectly cylindrical shape. The diameter and length of individual pellets were measured using an electronic caliper with an accuracy of $\pm 0.01 \mathrm{~mm}$. Pellet density was determined immediately following its ejection from the pelletizer and was reported as an average of six measurements per treatment combination. Moisture content was measured according to EN ISO 18134-3:2015 [19], and it was reported as an average of two measurements per treatment combination.

The compressive strength of pellets was determined following the procedure described in Nguyen, Cloutier, Achim, and Stevanovic [11]. The pellets produced were kept in vials and tested for compressive strength after production. A universal MTS testing machine (MTS Systems Coroporation, Eden Prairie, Minnesota, USA) was used to measure the peak load in transverse compression of the pellets. The pellet specimen was compressed radially between two parallel horizontal plates until it broke or showed signs of fracture. The compression speed was set to $6 \mathrm{~mm} \cdot \mathrm{min}^{-1}$. The ratio between the peak load in compression and the pellet length was defined as the compressive strength. An average of three measurements was used per treatment combination. 


\subsection{Data Analysis}

Analyses of variance (ANOVA) were performed to test the effects of the following factors on wood pellet quality: press temperature ( 2 levels: 100 and $\left.125^{\circ} \mathrm{C}\right)$, press compressive force ( 2 levels: 1500 and $2500 \mathrm{~N}$ ), moisture content of feedstock ( 3 levels: as is, $12 \%$, and 15\%), and composition of feedstock (10 levels: each level corresponds to proportions of residues from different origins, see Figure 2). The response variables were: pellet friction, density, and mechanical strength. All factors were tested separately and in interactions. A $p$-value of 0.05 was used as the limit for statistical significance using $\mathrm{R}$ programming statistical software.

A classification tree analysis was also performed to explore the structure of the dataset and identify decision rules for predicting pelletization characteristics (i.e., friction force) and pellet quality (pellet density and strength) based on the independent variables related to feedstock characteristics and pelletization parameters (blend composition and moisture content; temperature and compressive force). The analysis involved the segregation of different values of classification variables through a decision tree composed of progressive binary splits. Every value for each predictor variable was considered as a potential split, and the optimal split was selected based on how well the split reduced the heterogeneity within the resulting subsets. Each parent node in the decision tree produced two child nodes, which in turn could become parent nodes producing additional child nodes. This process continued with both tree building and pruning until statistical analysis indicated that the tree fit without overfitting the information contained in the dataset. The analysis was made using the Rpart package in R programming statistical software v.3.0.1 [25].

\section{Results}

\subsection{Properties of Residues}

The results of particle size distribution analysis and other characteristics of the four single residue sources (green wood chips, dry shavings, solid wood sawdust, and engineered wood sawdust) are presented in Figure 3 and Table 1. From Figure 3a, it can be seen that both types of sawdust contained large proportions of small particles, with about $70 \%$ of particles $<0.25 \mathrm{~mm}$. The largest proportions of shavings were retained in both 1.5 and $0.5 \mathrm{~mm}$ sieve opening sizes (Figure 3a), and the largest proportion of green wood chips was retained in the $9.5 \mathrm{~mm}$ tray (Figure $3 \mathrm{~b}$ ).

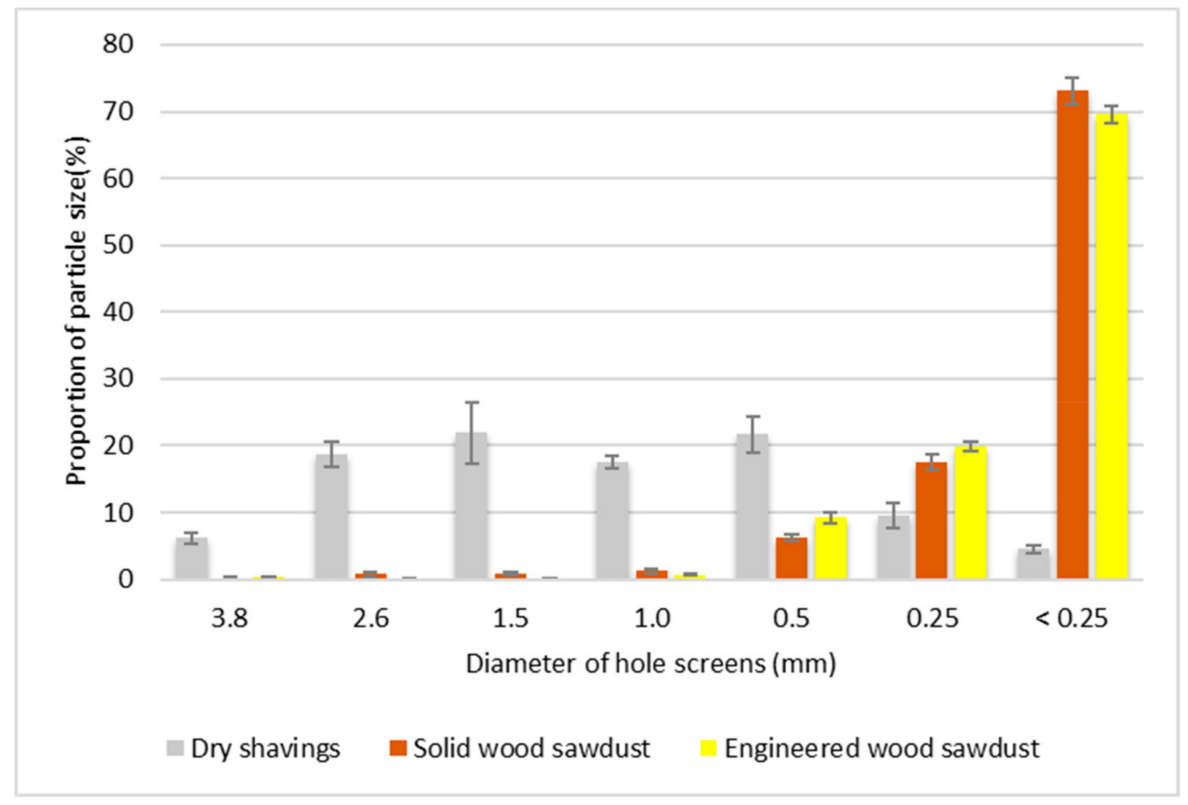

(a)

Figure 3. Cont. 


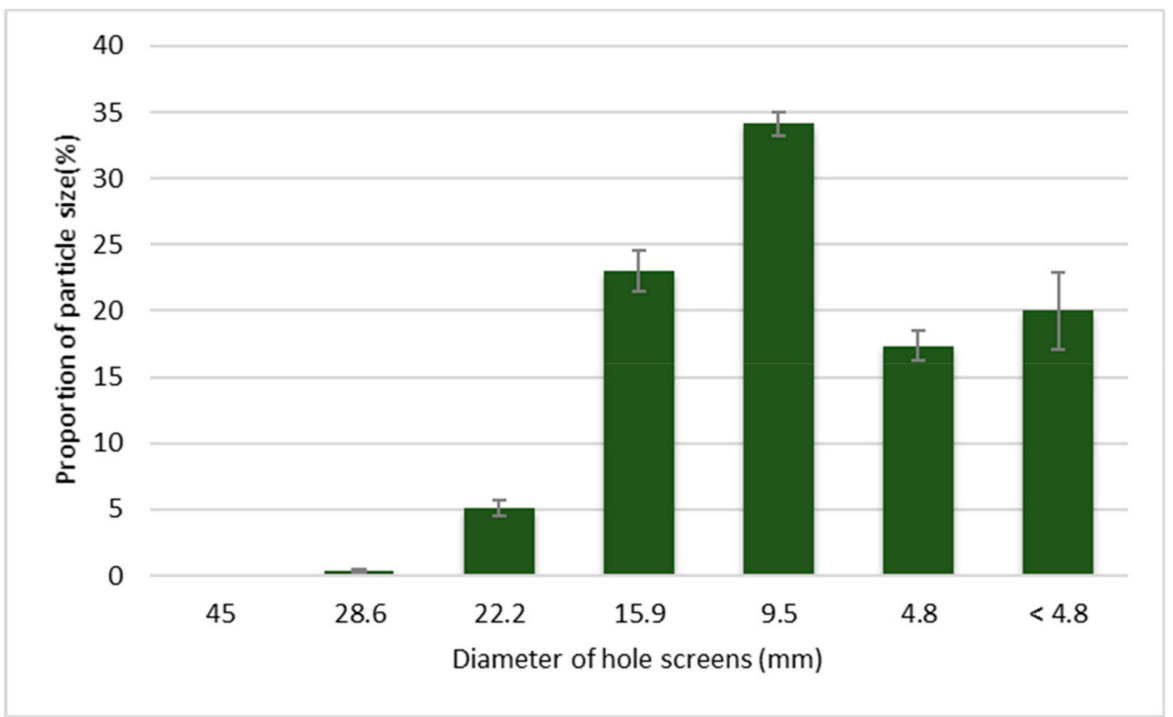

(b)

Figure 3. (a) Average proportion of shavings and sawdust by sieve opening sizes with their associated standard deviations. (b) Mean proportion of wood chips by hole screens size diameters with their associated standard deviations.

Table 1. Fuel quality related parameters (mean \pm standard deviation) of the four residue sources. Values represent averages of four samples. d.b. = dry basis, w.b. = wet basis.

\begin{tabular}{|c|c|c|c|c|}
\hline Parameter & $\begin{array}{c}\text { Dry } \\
\text { Shavings }\end{array}$ & $\begin{array}{l}\text { Solid Wood } \\
\text { Sawdust }\end{array}$ & $\begin{array}{c}\text { Engineered } \\
\text { Wood Sawdust }\end{array}$ & $\begin{array}{c}\text { Green Wood } \\
\text { Chips }\end{array}$ \\
\hline Moisture content (\%, d.b.) & $6.97 \pm 0.08$ & $8.21 \pm 0.31$ & $10.01 \pm 0.21$ & $42.91 \pm 2.17$ \\
\hline Moisture content (\%, w.b.) & $6.52 \pm 0.07$ & $7.59 \pm 0.27$ & $9.10 \pm 0.17$ & $30.02 \pm 1.07$ \\
\hline Bulk density $\left(\mathrm{kg} \mathrm{m}^{-3}\right)$ & $123 \pm 19$ & $195 \pm 12$ & $133 \pm 8$ & $52 \pm 5$ \\
\hline Higher heating value (MJ kg-1) & $19.7 \pm 0.1$ & $19.7 \pm 0.1$ & $19.4 \pm 0.1$ & $19.6 \pm 0.5$ \\
\hline \multicolumn{5}{|l|}{ Chemical composition (\%) } \\
\hline Extractives & $6.1 \pm 0.1$ & $8.1 \pm 0.2$ & $7.0 \pm 0.3$ & $5.1 \pm 0.4$ \\
\hline Cellulose & $51.0 \pm 0.8$ & $48.8 \pm 1.2$ & $50.1 \pm 1.4$ & $51.0 \pm 0.3$ \\
\hline Hemicellulose & $24.6 \pm 0.8$ & $24.5 \pm 0.6$ & $27.0 \pm 0.3$ & $26.7 \pm 0.9$ \\
\hline Lignin & $18.4 \pm 0.2$ & $18.6 \pm 1.0$ & $16.0 \pm 1.4$ & $17.2 \pm 0.3$ \\
\hline Ash & $0.43 \pm 0.03$ & $0.69 \pm 0.05$ & $0.60 \pm 0.04$ & $0.44 \pm 0.03$ \\
\hline \multicolumn{5}{|l|}{$\begin{array}{l}\text { Ultimate analysis } \\
\text { (wt \%, dry ash free) }\end{array}$} \\
\hline Carbon & $48.03 \pm 0.51$ & $48.01 \pm 0.19$ & $47.57 \pm 0.59$ & $48.95 \pm 0.21$ \\
\hline Nitrogen & $0.06 \pm 0.02$ & $0.07 \pm 0.00$ & $0.05 \pm 0.01$ & $0.06 \pm 0.00$ \\
\hline Sulfur & $0.01 \pm 0.01$ & $0.02 \pm 0.01$ & $0.02 \pm 0.01$ & $0.02 \pm 0.03$ \\
\hline \multicolumn{5}{|l|}{$\begin{array}{l}\text { Major element analysis } \\
\qquad\left(\mathrm{mg} \mathrm{kg}^{-1}\right)\end{array}$} \\
\hline $\mathrm{Al}$ & $680 \pm 129$ & $30 \pm 0$ & $110 \pm 140$ & $50 \pm 10$ \\
\hline $\mathrm{Ca}$ & $870 \pm 80$ & $1480 \pm 170$ & $760 \pm 100$ & $1200 \pm 90$ \\
\hline $\mathrm{Fe}$ & $0 \pm 0$ & $0 \pm 0$ & $10 \pm 10$ & $10 \pm 10$ \\
\hline K & $740 \pm 120$ & $520 \pm 40$ & $680 \pm 130$ & $360 \pm 40$ \\
\hline $\mathrm{Mg}$ & $20 \pm 70$ & $180 \pm 30$ & $290 \pm 110$ & $190 \pm 10$ \\
\hline $\mathrm{P}$ & $70 \pm 30$ & $40 \pm 10$ & $30 \pm 10$ & $80 \pm 40$ \\
\hline \multicolumn{5}{|l|}{$\begin{array}{l}\text { Minor element analysis } \\
\qquad\left(\mathrm{mg} \mathrm{kg}^{-1}\right)\end{array}$} \\
\hline $\mathrm{Cu}$ & $20 \pm 20$ & $10 \pm 10$ & $30 \pm 10$ & $40 \pm 20$ \\
\hline Mn & $40 \pm 10$ & $40 \pm 0$ & $40 \pm 20$ & $130 \pm 10$ \\
\hline $\mathrm{Zn}$ & $10 \pm 0$ & $10 \pm 0$ & $10 \pm 0$ & $20 \pm 0$ \\
\hline
\end{tabular}


Moisture content of feedstock is an important parameter because it influences feedstock behavior during storage as well as the calorific value and combustion efficiency of the final product. Moreover, in the pelletizing process, too much moisture can make the particles slippery and slide through the die holes, resulting in reduced pellet quality. On the other hand, when feedstock is too dry, it may plug the die channels if the resistance from the channel exceeds the compression force of the roller [26,27]. According to the literature, the critical limits of moisture content that can produce good quality pellets is around $10 \%$ [28]; raw material with a moisture content higher than $15 \%$ has been reported for being difficult to pelletize. In the present study, the average moisture contents of wood dry shavings, solid wood sawdust, engineered wood sawdust, and green wood chips were, on average, $7 \%, 8 \%, 10 \%$, and $43 \%$ (calculated on a dry basis), respectively (Table 1); variations among samples of the same source were not high, yielding relatively low standard deviations. From the requirement of moisture content in raw material for the production of pellets mentioned above, the primary limitation of green wood chips for the production of wood pellets was its high moisture content. Therefore, the use of appropriate proportions of residues from different sources (green wood chips, dry wood shavings, solid wood sawdust, and engineered wood sawdust) resulting in an optimal moisture content of mixed residues could offer a significant advantage in terms of conversion efficiency during the pelletization process.

Bulk density of the wood particles has also been reported to affect the conversion efficiency during the pelletization process. Data in Table 1 indicate that wood chips had an average bulk density of $52 \mathrm{~kg} \cdot \mathrm{m}^{-3}$, whereas the mean bulk density of solid wood sawdust reached $195 \mathrm{~kg} \cdot \mathrm{m}^{-3}$ (i.e., about four times denser than wood chips).

During the analysis of particle size distribution, numerous contaminants coming from the engineered wood sawdust were noticed (e.g., cardboard and metal pieces). Manufacturing processes of the engineered wood flooring production line and/or poor storage conditions for the sawdust might explain these contaminants.

A high proportion of lignin is often associated with a higher heating value [29]. Lignin also contributes to binding the particles during the pelletization process [30]. In this study, the lignin proportion varied only slightly among residue sources, from $16.0 \%$ to $18.4 \%$. That can explain the reason why there were no considerable differences in the HHV among the four types of wood residues. Also, the extractive concentration was interesting to monitor because woody biomass with high extractive content is more desirable as a fuel since it increases its calorific value [31-33]. In this study, the proportion of extractives was highest in solid wood sawdust and lowest in green wood chips. However, proportions of extractives and their variability (5\%-8\%) were probably not high enough as to affect the values of HHV for the four types of wood residues.

Ash content is another essential fuel property to be monitored because it can have negative impacts on combustion and conversion processes [12]. In the current study, the ash contents of dry shavings, solid wood sawdust, engineered wood sawdust, and green wood chips were respectively $0.43 \%, 0.69 \%, 0.60 \%$, and $0.44 \%$ (Table 1 ). These values are lower than the limit established by the European standards $(0.7 \%)$ for the production of high-quality solid biofuels such as wood briquettes and wood pellets [34]. Furthermore, lower ash content requires less frequent ash cleaning, which is important for the automatic operation of biomass boilers or stoves.

In addition to the ash content, the concentrations of the individual ash elements were measured, as they affect the ash-melting point. If the melting point is too low, deposit build-up and corrosion problems may arise $[28,35]$. Wood with high concentrations in $\mathrm{K}$ (and also $\mathrm{Na}$ ) could promote a decrease of the ash-melting point [36], while wood with high concentrations in Ca and $\mathrm{Mg}$ could increase it $[12,37]$. In this study (Table 1), all average $\mathrm{K}$ concentrations fell under the threshold set by the BS EN14961-1:2010 for hardwood fuels $\left(800 \mathrm{mg} \cdot \mathrm{kg}^{-1}\right)$ [34,38]. Average concentrations in $\mathrm{Mg}$ and Ca corresponded more or less to the typical values set by the standard (200 and $\left.1200 \mathrm{mg} \cdot \mathrm{kg}^{-1}\right)[34,38]$. However, the average concentration in $\mathrm{Al}$ measured in all residues was higher than the value established by the BS EN14961-1:2010 for hardwoods fuels $\left(20 \mathrm{mg} \cdot \mathrm{kg}^{-1}\right)$, especially for dry shavings $\left(680 \mathrm{mg} \cdot \mathrm{kg}^{-1}\right)$, which were outside the typical variation observed in hardwoods $\left(10-50 \mathrm{mg} \cdot \mathrm{kg}^{-1}\right)[34,38]$. 
The minor elements $(\mathrm{Cu}, \mathrm{Mn}, \mathrm{Zn})$ present in ash of the woody residues are also relevant for particulate emissions and environmental assessments. The measured average $\mathrm{Zn}$ concentrations generally fell below the typical value established by the BS EN14961-1:2010 for hardwood fuels, except for the green wood chips. The average $\mathrm{Cu}$ values for all materials varied between $10-40 \mathrm{mg} \cdot \mathrm{kg}^{-1}$, that is, they are an order of magnitude higher than the thresholds set by standards $\left(2 \mathrm{mg} \cdot \mathrm{kg}^{-1}\right)$. The average concentration in $\mathrm{Mn}$ in the green wood chips $\left(183 \mathrm{mg} \cdot \mathrm{kg}^{-1}\right)$ was also higher than the BS EN14961-1:2010 thresholds (83 $\mathrm{mg} \cdot \mathrm{kg}^{-1}$ ) [34,38] (Table 1). It is not clear if the high levels of $\mathrm{Al}$ and minor elements originate from machinery and equipment from the hardwood flooring production lines, from storage, or from the woody residues themselves. These high concentrations may limit the production of high-quality pellets.

The presence of $\mathrm{N}$ and $\mathrm{S}$ was also monitored as they can cause gaseous emissions of $\mathrm{NO}_{\mathrm{x}}$ and $\mathrm{SO}_{\mathrm{x}}$, one of the main environmental impacts of solid biofuel combustion [39]. In this study, the average proportions in nitrogen $(\mathrm{N})(0.05 \%-0.07 \%)$ and sulfur $(\mathrm{S})(0.01 \%-0.02 \%)$ were rather small (Table 1$)$. These values fell below or within the range reported by the BS EN14961-1:2010 for hardwood fuels $(\mathrm{N}<0.1 \%-0.5 \%$ and $\mathrm{S}<0.01 \%-0.05 \%)[34,38]$.

\subsection{Pelletizing Characteristics and Quality of Pellets}

Results of the particle size distribution of the ten combinations (blends) of mixed residues are presented in Table 2 along with other physical properties related to fuel quality. Moisture content of the blends varied between $6.8 \%$ and $16.8 \%$ (Table 2 ). As expected, blends composed of a larger proportion of green wood chips (Blends 2, 3, 7, and 9) were more humid than the ones prepared with a larger proportion of sawdust. Blends composed of a large proportion of sawdust at low moisture content had the highest bulk densities, while blends composed of a large proportion of green wood chips had the lowest bulk densities. The highest ash contents were observed with blends composed of a large proportion of sawdust (Table 2). The HHV appeared to be relatively stable throughout the blends, varying from 19.55 to $19.79 \mathrm{MJ} \cdot \mathrm{kg}^{-1}$. All studied blends could meet American and European standards for high-quality pellets. However, blends 9 and 10 had ash contents close to the upper limit set by the standards (0.7\%); the amount of sawdust, with its high ash content, would thus need to be carefully managed.

Results of the pelletizing characteristics (i.e., friction force) and pellet properties (density, moisture content, and mechanical strength) are presented in Table A1 of the Appendix A. Results of the ANOVAs testing the effect of the pelletizing (temperature and compressive force) and blend (composition and moisture content) parameters revealed several significant interactions between factors on their effects of pellet quality, described by pellet friction (Table 3), density (Table 4), and mechanical strength (Table 5). Interactions of blend moisture content and composition with other factors were particularly significant in explaining differences in wood pellet quality.

These interactions were exemplified with the tree regressions. Results from this analysis showed that blend moisture content was the parameter that had the greatest influence on pellet friction (Figure 4), followed by blend composition. Frictional forces varied from 8.91 (Blend 2, made of wood chips only) to $28.08 \mathrm{~N} \cdot \mathrm{mm}^{-1}$ (Blend 1 , made of dry shavings only). Within a same blend, the variation in the frictional force measurements appeared to be larger in blends with lower sawdust content. Figure 4 suggests that the lower the moisture content of the blended feedstocks, the higher the friction force. For example, a higher proportion of green chips in the blends resulted in higher moisture content ( $9.0 \%$ and higher), which lowered the friction force in the press channel of the pelletizer. The pelletizing process highly depends on the friction force between the compression channel and the densified raw material [12]. A lower friction during pelletizing should translate to a lower energy consumption when pelletizing with a large-scale pellet mill [40]. 
Table 2. Results of the particle size distribution analysis and other physical properties of ten blends (combinations) of residues. Values represent averages of three samples. d.b. $=$ dry basis

\begin{tabular}{|c|c|c|c|c|c|c|c|c|c|c|c|}
\hline \multicolumn{8}{|c|}{ Particle Size Distribution (\% per Diameter of Hole Screen) } & \multirow{2}{*}{$\begin{array}{l}\text { Moisture Content } \\
(\%, \text { d.b. })\end{array}$} & \multirow{2}{*}{$\begin{array}{l}\text { Bulk Density } \\
\left(\mathrm{kg} \mathrm{m}^{-3}\right)\end{array}$} & \multirow{2}{*}{$\begin{array}{l}\text { Higher Heating Value } \\
\left(\mathrm{MJ} \mathrm{kg}^{-1}\right)\end{array}$} & \multirow{2}{*}{$\begin{array}{c}\text { Ash Conten } \\
(\%)\end{array}$} \\
\hline Blend \# & $3.35 \mathrm{~mm}$ & $2.80 \mathrm{~mm}$ & $1.40 \mathrm{~mm}$ & $1.00 \mathrm{~mm}$ & $0.50 \mathrm{~mm}$ & $0.25 \mathrm{~mm}$ & $<0.25 \mathrm{~mm}$ & & & & \\
\hline 1 & 0.0 & 0.0 & 3.0 & 10.0 & 38.0 & 33.0 & 16.0 & 6.8 & 220 & 19.79 & 0.37 \\
\hline 2 & 0.0 & 0.0 & 15.0 & 23.0 & 36.0 & 18.0 & 8.0 & 16.8 & 99 & 19.69 & 0.44 \\
\hline 3 & 0.0 & 0.0 & 8.0 & 19.0 & 39.0 & 24.0 & 11.0 & 11.0 & 163 & 19.78 & 0.41 \\
\hline 4 & 0.0 & 0.0 & 3.0 & 9.0 & 31.0 & 28.0 & 28.0 & 6.9 & 236 & 19.72 & 0.47 \\
\hline 5 & 0.0 & 0.0 & 3.0 & 10.0 & 32.0 & 27.0 & 28.8 & 7.2 & 206 & 19.55 & 0.45 \\
\hline 6 & 0.0 & 0.0 & 2.0 & 5.0 & 21.0 & 24.0 & 47.0 & 7.5 & 235 & 19.79 & 0.53 \\
\hline 7 & 0.0 & 0.0 & 4.0 & 9.0 & 19.0 & 18.0 & 49.0 & 11.7 & 129 & 19.56 & 0.53 \\
\hline 8 & 0.0 & 0.0 & 2.0 & 7.0 & 24.0 & 25.0 & 42.0 & 7.8 & 185 & 19.69 & 0.52 \\
\hline 9 & 0.0 & 0.0 & 7.0 & 11.0 & 20.0 & 17.0 & 44.0 & 11.0 & 179 & 19.69 & 0.62 \\
\hline 10 & 0.0 & 0.0 & 5.0 & 10.0 & 21.0 & 19.0 & 45.0 & 10.0 & 169 & 19.74 & 0.60 \\
\hline
\end{tabular}

Table 3. Parameters and $p$-values from ANOVAs testing the effects of blend composition, moisture content, press compressive force, and temperature on pellet friction. $\mathrm{Df}=$ Degrees of freedom. Sum sq $=$ Sum of squares. Mean sq $=$ Mean square.

\begin{tabular}{|c|c|c|c|c|c|}
\hline Factor & Df & Sum sq & Mean sq & $F$-Value & $p$-Value \\
\hline Blend composition & 9 & 4459.4 & 495.49 & 109.2242 & $<0.001$ \\
\hline Blend moisture content & 2 & 1988.2 & 994.08 & 219.133 & $<0.001$ \\
\hline Press compressive force & 1 & 532.3 & 532.26 & 117.3301 & $<0.001$ \\
\hline Press temperature & 1 & 94.2 & 94.15 & 20.7551 & $<0.001$ \\
\hline Press compressive force: Blend composition & 9 & 93.3 & 10.37 & 2.2857 & 0.015 \\
\hline Press temperature: Blend composition & 9 & 386.6 & 42.95 & 9.4686 & $<0.001$ \\
\hline Blend moisture content: Blend composition & 18 & 2842.9 & 157.94 & 34.8159 & $<0.001$ \\
\hline Press compressive force: Blend moisture content & 2 & 175.6 & 87.81 & 19.3562 & $<0.001$ \\
\hline Press compressive force: Press temperature & 1 & 11 & 10.96 & 2.4161 & 0.121 \\
\hline Blend moisture content: Press temperature & 2 & 84.9 & 42.45 & 9.3569 & $<0.001$ \\
\hline Press compressive force: Blend moisture content: Press temperature & 2 & 0.3 & 0.16 & 0.0356 & 0.965 \\
\hline Press compressive force: Blend moisture content: Blend composition & 18 & 255.6 & 14.2 & 3.1303 & $<0.001$ \\
\hline Press compressive force: Press temperature: Blend composition & 9 & 151.3 & 16.81 & 3.7055 & $<0.001$ \\
\hline Blend moisture content: Press temperature: Blend composition & 18 & 351.7 & 19.54 & 4.3074 & $<0.001$ \\
\hline $\begin{array}{l}\text { Press compressive force: Blend moisture content: Press temperature: Blend } \\
\text { composition }\end{array}$ & 18 & 115.4 & 6.41 & 1.4133 & 0.118 \\
\hline Residuals & 596 & 2703.7 & 4.54 & & \\
\hline
\end{tabular}


Table 4. Parameters and p-values from ANOVAs testing the effects of blend composition, moisture content, press compressive force, and temperature on pellet density. $\mathrm{Df}=$ Degrees of freedom. Sum $\mathrm{sq}=$ Sum of squares. Mean $\mathrm{sq}=$ Mean square.

\begin{tabular}{|c|c|c|c|c|c|}
\hline Factor & Df & Sum sq & Mean sq & F-Value & $p$-Value \\
\hline Blend composition & 9 & 679,781 & 75,531 & 23.2459 & $<0.001$ \\
\hline Blend moisture content & 2 & 622,911 & 311,456 & 95.8554 & $<0.001$ \\
\hline Press compressive force & 1 & 439,546 & 439,546 & 135.2774 & $<0.001$ \\
\hline Press temperature & 1 & 232,895 & 232,895 & 71.6771 & $<0.001$ \\
\hline Press compressive force: Blend composition & 9 & 36,322 & 4036 & 1.2421 & 0.266 \\
\hline Press temperature: Blend composition & 9 & 96,469 & 10,719 & 3.2989 & $<0.001$ \\
\hline Blend moisture content: Blend composition & 18 & 380,266 & 21,126 & 6.5018 & $<0.001$ \\
\hline Press compressive force: Blend moisture content & 2 & 63,947 & 31,973 & 9.8404 & $<0.001$ \\
\hline Press compressive force: Press temperature & 1 & 94 & 94 & 0.0289 & 0.865 \\
\hline Blend moisture content: Press temperature & 2 & 7466 & 3733 & 1.1489 & 0.317 \\
\hline $\begin{array}{c}\text { Press compressive force: Blend moisture content: } \\
\text { Press temperature }\end{array}$ & 2 & 8885 & 4443 & 1.3673 & 0.255 \\
\hline $\begin{array}{c}\text { Press compressive force: Blend moisture content: } \\
\text { Blend composition }\end{array}$ & 18 & 78,938 & 4385 & 1.3497 & 0.151 \\
\hline Press compressive force: Press temperature: Blend composition & 9 & 38,329 & 4259 & 1.3107 & 0.228 \\
\hline Blend moisture content: Press temperature: Blend composition & 18 & 81,155 & 4509 & 1.3876 & 0.131 \\
\hline $\begin{array}{c}\text { Press compressive force: Blend moisture content: Press } \\
\text { temperature: Blend composition }\end{array}$ & 18 & 42,871 & 2382 & 0.733 & 0.778 \\
\hline Residuals & 600 & $1,949,534$ & 3249 & & \\
\hline
\end{tabular}


Table 5. Parameters and $p$-values from ANOVAs testing the effects of blend composition, moisture content, press compressive force, and temperature on pellet mechanical strength. $\mathrm{Df}=$ Degrees of freedom. Sum $\mathrm{sq}=$ Sum of squares. Mean sq = Mean square.

\begin{tabular}{|c|c|c|c|c|c|}
\hline Factor & Df & Sum sq & Mean sq & F-Value & $p$-Value \\
\hline Press compressive force & 1 & 3649.4 & 3649.4 & 84.4256 & $<0.001$ \\
\hline Blend moisture content & 2 & 9155.2 & 4577.6 & 105.8972 & $<0.001$ \\
\hline Press temperature & 1 & $13,419.2$ & $13,419.2$ & 310.4363 & $<0.001$ \\
\hline Blend composition & 9 & $26,164.4$ & 2907.2 & 67.2535 & $<0.001$ \\
\hline Press compressive force: Blend composition & 9 & 2005.9 & 222.9 & 5.156 & $<0.001$ \\
\hline Press temperature: Blend composition & 9 & 1994.8 & 221.6 & 5.1276 & $<0.001$ \\
\hline Blend moisture content: Blend composition & 18 & 5842.5 & 324.6 & 7.5089 & $<0.001$ \\
\hline Press compressive force: Blend moisture content & 2 & 855.2 & 427.6 & 9.8926 & $<0.001$ \\
\hline Press compressive force: Press temperature & 1 & 32.5 & 32.5 & 0.753 & 0.386 \\
\hline Blend moisture content: Press temperature & 2 & 144 & 72 & 1.6658 & 0.191 \\
\hline Press compressive force: Blend moisture content: Press temperature & 2 & 0.6 & 0.3 & 0.0072 & 0.993 \\
\hline Press compressive force: Blend moisture content: Blend composition & 18 & 1000.9 & 55.6 & 1.2863 & 0.197 \\
\hline Press compressive force: Press temperature: Blend composition & 9 & 405.1 & 45 & 1.0412 & 0.408 \\
\hline Blend moisture content: Press temperature: Blend composition & 18 & 1407.4 & 78.2 & 1.8088 & 0.025 \\
\hline $\begin{array}{l}\text { Press compressive force: Blend moisture content: Press temperature: } \\
\text { Blend composition }\end{array}$ & 18 & 956.9 & 53.2 & 1.2298 & 0.238 \\
\hline Residuals & 240 & $10,374.4$ & 43.2 & & \\
\hline
\end{tabular}




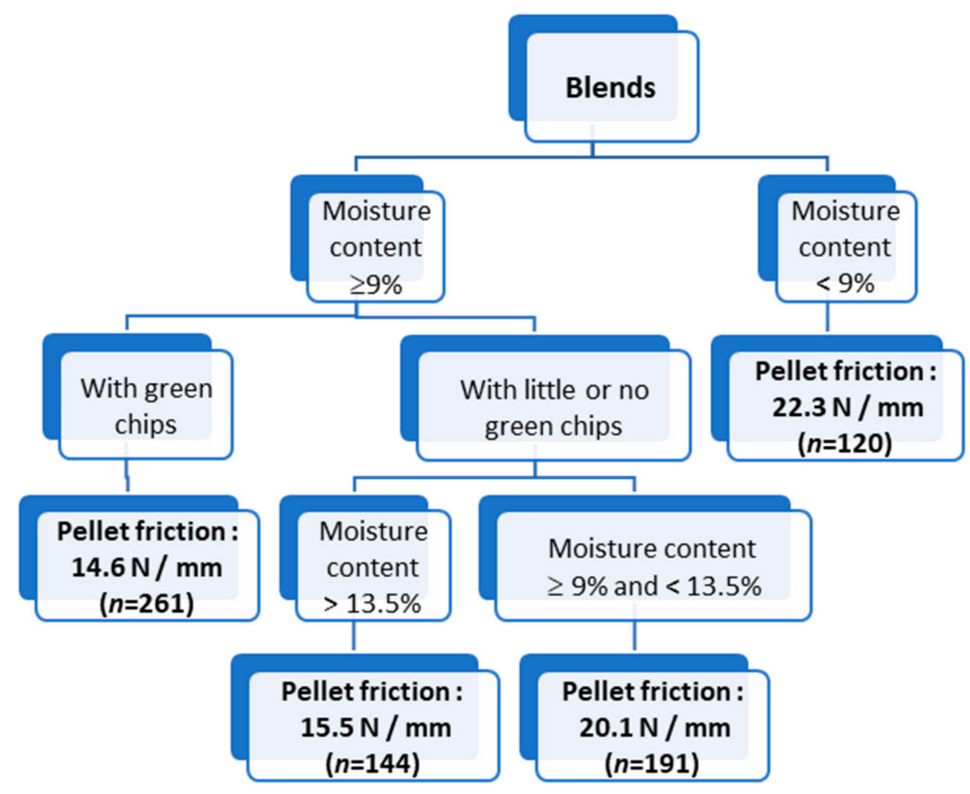

Figure 4. Regression tree of pellet friction, with averages and number of observations (in parentheses).

The average density of pellets varied from 904 (Blend 1; made of dry shavings only) to $1195 \mathrm{~kg} \cdot \mathrm{m}^{-3}$ (Blend 6; made of 50\% dry shavings and 50\% solid wood sawdust) (Appendix A). The regression tree demonstrated that the blend moisture content was again the most important parameter, followed by the compressive force (Figure 5). No matter the blend composition, a higher moisture content (i.e., $\geq 13.5 \%$ ) resulted in a lower pellet density $\left(1019 \mathrm{~kg} \cdot \mathrm{m}^{-3}\right)$. When pressed under $2000 \mathrm{~N}$, the pellet density decreased $\left(1059 \mathrm{~kg} \cdot \mathrm{m}^{-3}\right)$ while it increased at a higher compressive force (i.e., $\left.>2000 \mathrm{~N} ; 1122 \mathrm{~kg} \cdot \mathrm{m}^{-3}\right)$. Blends 5, 7, 8, and 10, which contained engineered wood sawdust, yielded a higher pellet density, which should translate into a longer burnout time.

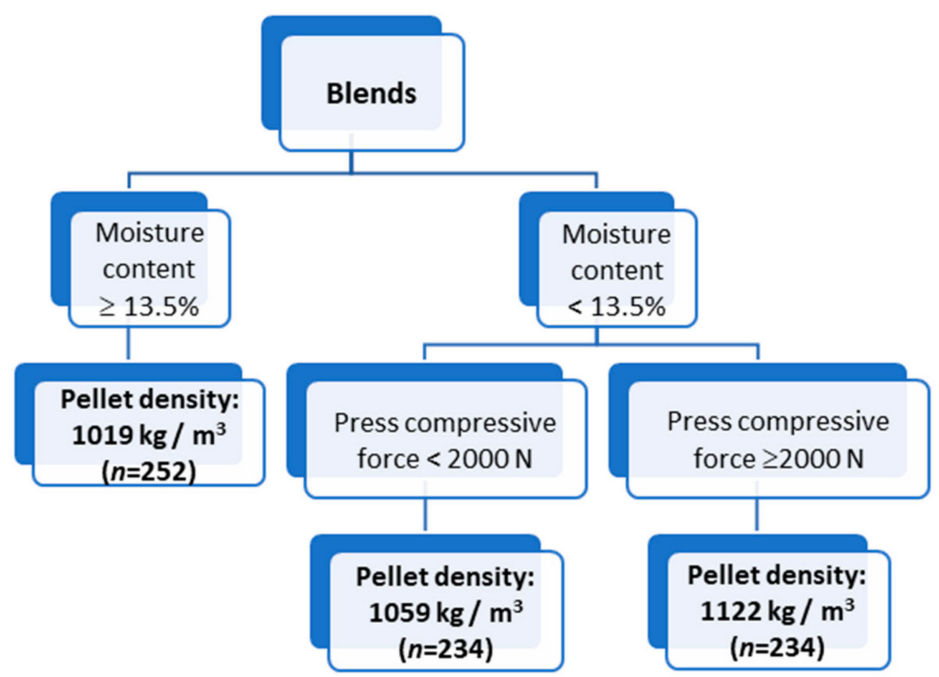

Figure 5. Regression tree of pellet density, with averages and number of observations (in parentheses).

In the present study, the moisture content of pellets varied from $1.0 \%$ to about $9.0 \%$ (Appendix A). The ideal moisture content of wood pellets should be at $10.0 \%$ or less [12]. At higher moisture content (especially above $20.0 \%$ ), bacteria may develop and cause degradation for woody biomass and pellets [41]. Among the treatment combinations of a same blend, the moisture content varied by about $6 \%$. This shows how other parameters not related to the initial feedstock properties can also affect the result of the pellets' properties. In this study, moisture content of pellets tended to decrease 
more importantly when prepared at high temperature $\left(125^{\circ} \mathrm{C}\right)$, but it was only slightly affected by the strength of the compressive forces during pelletization.

The mechanical strength of pellets varied from 24.78 (Blend 1: $100 \%$ dry shavings) to $86.88 \mathrm{~N} \cdot \mathrm{mm}^{-1}$ (Blend 8: 50\% engineered wood sawdust and 50\% dry shavings) (Appendix A). The regression tree analysis demonstrated that blend composition was the most important factor affecting the mechanical properties of wood pellets (Figure 6). The press temperature and compressive force as well as the blend moisture content were of second importance. Data in Figure 6 indicate that pellets made of blends without engineered wood sawdust (Blends 1, 2, 3, 4, 6, and 9) had lower mechanical strength than other blends containing $25 \%$ to $50 \%$ of engineered wood sawdust (Blends $5,7,8$, and 10). Blends of wood residues without sawdust, when pressed at low temperature $\left(<112.5^{\circ} \mathrm{C}\right)$, resulted in pellets with a lower mechanical strength $\left(38.4 \mathrm{~N} \cdot \mathrm{mm}^{-1}\right)$ compared to those pressed at higher temperature $\left(\geq 112.5^{\circ} \mathrm{C}\right)\left(49.5 \mathrm{~N} \cdot \mathrm{mm}^{-1}\right)$. The blends containing engineered wood sawdust when pressed at moisture content of $13.5 \%$ or above resulted in pellets produced with a lower mechanical strength $\left(47.6 \mathrm{~N} \cdot \mathrm{mm}^{-1}\right)$ compared to those made at low moisture content $(<13.5 \%)$. Results also indicated that a compressive force above $2000 \mathrm{~N}$ should be employed to press the blends into pellets with the best mechanical strength $\left(72.7 \mathrm{~N} \cdot \mathrm{mm}^{-1}\right)$, whereas a compressive force less than $2000 \mathrm{~N}$ resulted in pellets produced with much lower strength $\left(58.3 \mathrm{~N} \mathrm{~mm}^{-1}\right)$.

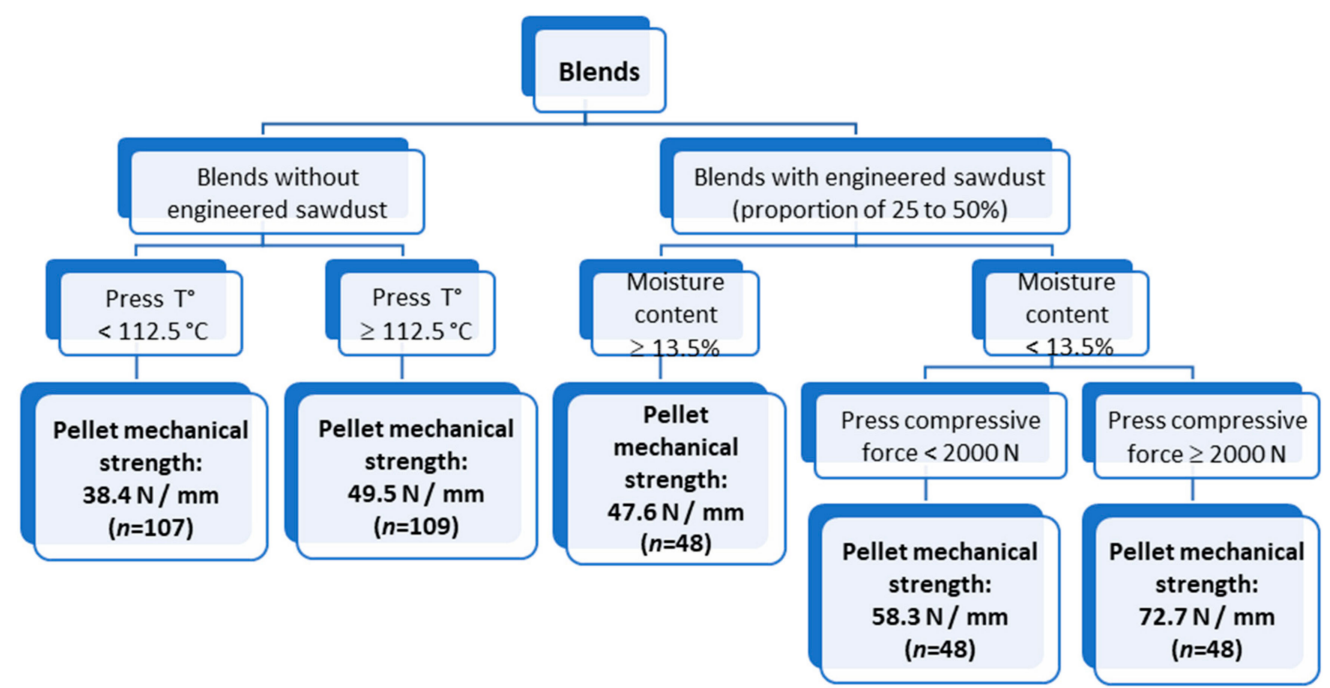

Figure 6. Regression tree of pellet mechanical strength $(n=360)$, with averages and number of observations (in parentheses).

Results are coherent with other studies [11,42] that reported that optimal compression strength tends to be lower with an increase in particle size and moisture content. In general, we observed that mechanical strength tended to increase with an increase in compressive force and temperature, while it decreased with high moisture content (Appendix A). Achieving the right combination of temperature and feedstock moisture content can ease the plastic deformation of the particles and help promote binding between them to produce high-quality pellets.

\section{Discussion}

Overall, our results suggest that the ideal mixture that would optimize pellet friction, density, and strength would contain from $25 \%-50 \%$ engineered sawdust and a portion of green chips, and it would have a moisture content of $9 \%-13.5 \%$; it would be need to pelletized using a compressive force $\geq 2000 \mathrm{~N}$. The blend's moisture content and composition were the most important parameters for determining pellet quality; pelletizing process parameters (press temperature and compression force) appeared to have less influence. As observed in other studies [11,42], the blends composed of a higher proportion of sawdust produced pellets with better mechanical properties (mechanical strength and 
density). In our study, sawdust from the engineered flooring line, generated by sawing of wood pieces, with its slightly lower bulk density, provided higher-quality pellets than the sawdust from solid wood flooring production that is generated by board trimming and edging (which is performed by a wider kerf). However, the quantity of sawdust added to the blend must be closely monitored as it may increase the ash concentration of the final product and, thus, restrict the uses of the wood pellets in power stations. The blends composed of a certain proportion of green chips also allowed to reduce the frictional force in the press.

Most of the parameters tested on the diverse sources of mill residues revealed interesting physical and chemical properties for wood pellet production. However, if mill residues were to be used for wood pellet production, the ash minor and major elements of residues would require further testing, as these were higher than thresholds established by the BS EN14961-1:2010. It is unclear whether these concentrations were due to wood inherent characteristics, flooring manufacturing processes, or suboptimal storage and handling conditions for the residues.

\section{Conclusions}

This study characterized properties of four different types of residues generated along the production lines of hardwood flooring, assessed their suitability for pellet production, and determined optimal feedstock and pelletizing conditions for high-quality pellets. It was based on small-scale experiments using a single pelletizer; therefore, results might not adequately represent industrial-scale operations. Nevertheless, results of this study suggest feedstock moisture content and composition, which can be controlled by proper blending of residues from different sources, are the most important parameters determining pellet quality. Pelletizing process parameters (press temperature and compression force) appeared to have less influence on the overall pellet quality, although settings can be optimized as a function of feedstock properties. The optimal blend of residues would contain from $25 \%-50 \%$ sawdust generated by the sawing of wood pieces and a portion of green chips (generated by the initial trimming of green wood logs); the ideal moisture content of blended feedstock is between $9 \%-13.5 \%$; it would need to be pelletized using a compressive force $\geq 2000 \mathrm{~N}$. However, residues (especially sawdust) contained high levels of metals and contaminants, which may have been brought by manufacturing and/or storage and handling processes. This suggests that a higher quality control on supply processes for residues needs to be put in place in order to obtain suitable feedstock for profitable production of pellets.

Progress has been important on technological aspects of woody biomass combustion. However, evidence suggests that success of forest bioenergy business cases often hinges on a tight management of feedstock quality, an aspect that is often neglected in the bioenergy sector [43], especially when the feedstock is a byproduct or residue from other processes. The quality of the bioenergy end-product can be significantly improved, and production costs reduced, by close integration of production lines of conventional forest products (such as flooring) and bioenergy products [44]. Developing more formal relationships between the type of process that generates residues (e.g., planning, trimming, sawing), and the physical and chemical properties of residues hence generated (which can then be used to predict pellet quality), would greatly contribute to the optimization of pellet production by reducing uncertainty associated with the "trial-and-error" method too often used in current pellet production.

Author Contributions: Conceptualization, E.T., J.B., and P.B.; Formal analysis, E.T. and J.B.; Funding acquisition, P.B.; Methodology, E.T., J.B., Q.N.N., and K.A.; Writing—original draft, E.T., J.B. and Q.N.N.; Writing一review \& editing, E.T., J.B., P.B. and K.A.

Funding: This project was funded by a grant to P. Blanchet from the Engage program of the Natural Science and Engineering Research Council, with the partnership of Preverco. We also acknowledge the Fonds de Recherche du Québec-Nature et Technologies for providing a post-doctoral scholarship to J. Barrette, and BioFuelNet Canada for providing financial support to E. Thiffault. Our gratitude goes to Fanny Michaud (RNCAN), Claude Durocher, Luc Germain, David Lagueux, and Yves Bédard (all from Laval University) for their precious help in the labs.

Acknowledgments: Our gratitude goes to Fanny Michaud (RNCAN), Claude Durocher, Luc Germain, David Lagueux, and Yves Bédard (all from Laval University) for their precious help in the labs. 
Conflicts of Interest: The authors declare no conflict of interest.

\section{Appendix A}

Table A1. Effect of combinations of feedstock moisture content, pelletizing compressive force, and temperature on pellet moisture content, friction force, density, and strength. Values are averages (standard deviation) of six replicates.

\begin{tabular}{|c|c|c|c|c|c|c|c|c|c|c|c|c|}
\hline \multirow{3}{*}{$\begin{array}{c}\begin{array}{c}\text { Feedstock Moisture } \\
\text { Content }(\%)\end{array} \\
\text { Compressive Force }(\mathrm{N}) \\
\text { Temperature }\left({ }^{\circ} \mathrm{C}\right) \\
\end{array}$} & \multicolumn{4}{|c|}{12} & \multicolumn{4}{|c|}{15} & \multicolumn{4}{|c|}{ As Received } \\
\hline & \multicolumn{2}{|c|}{1500} & \multicolumn{2}{|c|}{2500} & \multicolumn{2}{|c|}{1500} & \multicolumn{2}{|c|}{2500} & \multicolumn{2}{|c|}{1500} & \multicolumn{2}{|c|}{2500} \\
\hline & 100 & 125 & 100 & 125 & 100 & 125 & 100 & 125 & 100 & 125 & 100 & 125 \\
\hline Blend \# & \multicolumn{12}{|c|}{ Pellet Moisture Content } \\
\hline 1 & $\begin{array}{l}6.57 \\
(0.05)\end{array}$ & $\begin{array}{c}2.79 \\
(0.18)\end{array}$ & $\begin{array}{c}7.10 \\
(.)\end{array}$ & $\begin{array}{c}3.15 \\
(.)\end{array}$ & $\begin{array}{l}8.39 \\
(0.48)\end{array}$ & $\begin{array}{l}3.13 \\
(0.00)\end{array}$ & $\begin{array}{c}8.49 \\
(0.09)\end{array}$ & $\begin{array}{l}2.88 \\
(0.13)\end{array}$ & $\begin{array}{l}4.51 \\
(0.17)\end{array}$ & $\begin{array}{l}2.68 \\
(0.63)\end{array}$ & $\begin{array}{l}5.26 \\
(0.21)\end{array}$ & $\begin{array}{l}3.88 \\
(1.94)\end{array}$ \\
\hline 2 & $\begin{array}{l}5.94 \\
(2.68)\end{array}$ & $\begin{array}{c}1.42 \\
(0.93)\end{array}$ & $\begin{array}{l}7.28 \\
(0.14)\end{array}$ & $\begin{array}{c}2.16 \\
(0.11)\end{array}$ & $\begin{array}{c}9.16 \\
(1.91)\end{array}$ & $\begin{array}{l}2.92 \\
(0.13)\end{array}$ & $\begin{array}{l}8.07 \\
(0.51)\end{array}$ & $\begin{array}{l}1.88 \\
(0.61)\end{array}$ & $\begin{array}{l}7.31 \\
(2.54)\end{array}$ & $\begin{array}{l}2.76 \\
(1.04)\end{array}$ & $\begin{array}{l}8.03 \\
(0.00)\end{array}$ & $\begin{array}{l}2.39 \\
(0.26)\end{array}$ \\
\hline 3 & $\begin{array}{c}6.51 \\
(0.10)\end{array}$ & $\begin{array}{l}1.78 \\
(0.21)\end{array}$ & $\begin{array}{l}6.37 \\
(0.14)\end{array}$ & $\begin{array}{l}2.00 \\
(0.11)\end{array}$ & $\begin{array}{l}6.07 \\
(2.72)\end{array}$ & $\begin{array}{c}2.33 \\
(0.34)\end{array}$ & $\begin{array}{l}6.16 \\
(0.80)\end{array}$ & $\begin{array}{c}2.57 \\
(0.00)\end{array}$ & $\begin{array}{c}6.51 \\
(0.10)\end{array}$ & $\begin{array}{l}1.78 \\
(0.21)\end{array}$ & $\begin{array}{l}6.37 \\
(0.14)\end{array}$ & $\begin{array}{l}2.00 \\
(0.11)\end{array}$ \\
\hline 4 & $\begin{array}{c}5.64 \\
(.)\end{array}$ & $\begin{array}{c}1.08 \\
(0.81)\end{array}$ & $\begin{array}{l}5.98 \\
(0.09)\end{array}$ & $\begin{array}{l}2.00 \\
(0.66)\end{array}$ & $\begin{array}{l}7.57 \\
(0.46)\end{array}$ & $\begin{array}{c}1.36 \\
(1.01)\end{array}$ & $\begin{array}{c}6.91 \\
(0.09)\end{array}$ & $\begin{array}{c}2.17 \\
(0.04)\end{array}$ & $\begin{array}{l}4.84 \\
(0.07)\end{array}$ & $\begin{array}{l}1.79 \\
(0.12)\end{array}$ & $\begin{array}{l}4.53 \\
(0.52)\end{array}$ & $\begin{array}{c}2.31 \\
(0.19)\end{array}$ \\
\hline 5 & $\begin{array}{l}5.34 \\
(0.39)\end{array}$ & $\begin{array}{l}0.99 \\
(0.96)\end{array}$ & $6.05()$. & $\begin{array}{l}1.40 \\
(0.49)\end{array}$ & $\begin{array}{l}7.75 \\
(0.50)\end{array}$ & $\begin{array}{l}1.42 \\
(0.40)\end{array}$ & $\begin{array}{l}7.94 \\
(0.40)\end{array}$ & $\begin{array}{c}1.71 \\
(0.72)\end{array}$ & $\begin{array}{l}4.16 \\
(0.07)\end{array}$ & $\begin{array}{l}2.67 \\
(0.38)\end{array}$ & $\begin{array}{l}4.72 \\
(0.21)\end{array}$ & $\begin{array}{l}2.38 \\
(0.49)\end{array}$ \\
\hline 6 & $\begin{array}{l}5.78 \\
(0.29) \\
\end{array}$ & $\begin{array}{l}2.12 \\
(0.57) \\
\end{array}$ & $\begin{array}{c}6.77 \\
(0.06) \\
\end{array}$ & $\begin{array}{c}2.78 \\
(0.02) \\
\end{array}$ & $()$. & $\begin{array}{l}3.07 \\
(0.31) \\
\end{array}$ & $\begin{array}{l}8.32 \\
(0.01) \\
\end{array}$ & $\begin{array}{l}3.34 \\
(0.87) \\
\end{array}$ & $\begin{array}{l}4.39 \\
(0.11) \\
\end{array}$ & $\begin{array}{l}1.63 \\
(0.26) \\
\end{array}$ & $\begin{array}{l}4.68 \\
(0.19) \\
\end{array}$ & $\begin{array}{l}2.95 \\
(0.20) \\
\end{array}$ \\
\hline 7 & $\begin{array}{l}7.06 \\
(0.26)\end{array}$ & $\begin{array}{c}2.73 \\
(0.25)\end{array}$ & $\begin{array}{l}7.27 \\
(0.44) \\
\end{array}$ & $\begin{array}{c}2.69 \\
(0.68) \\
\end{array}$ & $\begin{array}{c}9.07 \\
(0.35)\end{array}$ & $\begin{array}{l}3.37 \\
(0.53)\end{array}$ & $\begin{array}{c}8.05 \\
(1.12)\end{array}$ & $\begin{array}{l}3.33 \\
(0.54)\end{array}$ & $\begin{array}{l}7.06 \\
(0.26) \\
\end{array}$ & $\begin{array}{l}2.73 \\
(0.25) \\
\end{array}$ & $\begin{array}{l}7.27 \\
(0.44) \\
\end{array}$ & $\begin{array}{l}2.69 \\
(0.68) \\
\end{array}$ \\
\hline 8 & $\begin{array}{c}6.25 \\
(.) \\
\end{array}$ & $\begin{array}{c}3.05 \\
(.)\end{array}$ & $\begin{array}{c}6.15 \\
(.)\end{array}$ & $\begin{array}{c}2.75 \\
(.)\end{array}$ & $\begin{array}{l}8.38 \\
(0.19) \\
\end{array}$ & $\begin{array}{c}3.01 \\
(0.79) \\
\end{array}$ & $\begin{array}{l}8.69 \\
(0.07)\end{array}$ & $\begin{array}{c}2.91 \\
(0.21)\end{array}$ & $\begin{array}{l}5.05 \\
(0.09) \\
\end{array}$ & $\begin{array}{l}2.52 \\
(0.37) \\
\end{array}$ & $\begin{array}{l}5.34 \\
(0.45) \\
\end{array}$ & $\begin{array}{l}2.48 \\
(0.39) \\
\end{array}$ \\
\hline 9 & $\begin{array}{l}6.84 \\
(0.19)\end{array}$ & $\begin{array}{l}1.76 \\
(0.10)\end{array}$ & $\begin{array}{l}6.18 \\
(0.21)\end{array}$ & $\begin{array}{c}2.08 \\
(0.51) \\
\end{array}$ & $\begin{array}{l}8.45 \\
(0.54)\end{array}$ & $\begin{array}{l}2.48 \\
(0.14)\end{array}$ & $\begin{array}{l}7.98 \\
(0.37)\end{array}$ & $\begin{array}{l}3.37 \\
(0.40)\end{array}$ & $\begin{array}{l}6.48 \\
(0.19) \\
\end{array}$ & $\begin{array}{l}1.76 \\
(0.10) \\
\end{array}$ & $\begin{array}{l}6.18 \\
(0.20)\end{array}$ & $\begin{array}{l}2.08 \\
(0.51)\end{array}$ \\
\hline \multirow[t]{2}{*}{10} & $\begin{array}{l}5.73 \\
(0.16)\end{array}$ & $\begin{array}{l}1.77 \\
(0.06)\end{array}$ & $\begin{array}{l}6.35 \\
(0.14)\end{array}$ & $\begin{array}{l}1.53 \\
(0.76)\end{array}$ & $\begin{array}{l}8.99 \\
(0.19)\end{array}$ & $\begin{array}{c}2.60 \\
(0.14)\end{array}$ & $\begin{array}{l}8.49 \\
(0.81)\end{array}$ & $\begin{array}{c}2.92 \\
(0.29)\end{array}$ & $\begin{array}{l}5.73 \\
(0.16)\end{array}$ & $\begin{array}{l}1.77 \\
(0.06)\end{array}$ & $\begin{array}{c}6.35 \\
(0.14)\end{array}$ & $\begin{array}{l}1.53 \\
(0.76)\end{array}$ \\
\hline & \multicolumn{12}{|c|}{ Pellet friction force $\left(\mathrm{N} \cdot \mathrm{mm}^{-1}\right)$} \\
\hline 1 & $\begin{array}{l}18.96 \\
(1.20)\end{array}$ & $\begin{array}{l}22.11 \\
(3.02)\end{array}$ & $\begin{array}{l}22.30 \\
(2.18)\end{array}$ & $\begin{array}{l}21.97 \\
(2.01)\end{array}$ & $\begin{array}{l}14.38 \\
(1.18)\end{array}$ & $\begin{array}{l}16.80 \\
(2.10)\end{array}$ & $\begin{array}{l}16.92 \\
(1.83)\end{array}$ & $\begin{array}{l}18.33 \\
(1.44)\end{array}$ & $\begin{array}{l}22.11 \\
(1.25)\end{array}$ & $\begin{array}{l}24.14 \\
(0.93)\end{array}$ & $\begin{array}{l}28.08 \\
(2.26)\end{array}$ & $\begin{array}{l}25.96 \\
(1.58)\end{array}$ \\
\hline 2 & $\begin{array}{l}10.71 \\
(1.06)\end{array}$ & $\begin{array}{c}8.91 \\
(2.81)\end{array}$ & $\begin{array}{l}14.99 \\
(1.48)\end{array}$ & $\begin{array}{l}11.70 \\
(0.41)\end{array}$ & $\begin{array}{l}22.65 \\
(2.17)\end{array}$ & $\begin{array}{l}17.16 \\
(1.57)\end{array}$ & $\begin{array}{l}24.51 \\
(1.45)\end{array}$ & $\begin{array}{l}13.66 \\
(1.05)\end{array}$ & $\begin{array}{l}12.75 \\
(1.31)\end{array}$ & $\begin{array}{l}14.89 \\
(5.99)\end{array}$ & $\begin{array}{l}15.87 \\
(1.81)\end{array}$ & $\begin{array}{l}14.09 \\
(3.91)\end{array}$ \\
\hline 3 & $\begin{array}{l}18.94 \\
(1.02)\end{array}$ & $\begin{array}{l}17.57 \\
(1.81)\end{array}$ & $\begin{array}{l}22.38 \\
(2.34)\end{array}$ & $\begin{array}{l}20.70 \\
(2.90) \\
\end{array}$ & $\begin{array}{l}20.66 \\
(1.54)\end{array}$ & $\begin{array}{l}16.65 \\
(1.96)\end{array}$ & $\begin{array}{l}21.10 \\
(1.92)\end{array}$ & $\begin{array}{l}17.20 \\
(1.35)\end{array}$ & $\begin{array}{l}18.94 \\
(1.02)\end{array}$ & $\begin{array}{l}17.57 \\
(1.81) \\
\end{array}$ & $\begin{array}{l}22.38 \\
(2.34)\end{array}$ & $\begin{array}{l}20.70 \\
(2.90) \\
\end{array}$ \\
\hline 4 & $\begin{array}{l}17.65 \\
(1.20)\end{array}$ & $\begin{array}{l}17.56 \\
(1.75)\end{array}$ & $\begin{array}{l}20.22 \\
(1.77)\end{array}$ & $\begin{array}{l}20.85 \\
(1.47)\end{array}$ & $\begin{array}{l}14.09 \\
(1.97)\end{array}$ & $\begin{array}{l}16.29 \\
(2.28)\end{array}$ & $\begin{array}{l}15.90 \\
(0.82)\end{array}$ & $\begin{array}{l}15.45 \\
(2.01)\end{array}$ & $\begin{array}{l}18.06 \\
(2.61)\end{array}$ & $\begin{array}{l}19.11 \\
(2.12)\end{array}$ & $\begin{array}{l}21.01 \\
(2.56)\end{array}$ & $\begin{array}{l}22.59 \\
(1.53)\end{array}$ \\
\hline 5 & $\begin{array}{l}19.92 \\
(2.20)\end{array}$ & $\begin{array}{l}19.37 \\
(2.49)\end{array}$ & $\begin{array}{l}22.83 \\
(1.95)\end{array}$ & $\begin{array}{l}18.97 \\
(2.63)\end{array}$ & $\begin{array}{l}15.05 \\
(1.23)\end{array}$ & $\begin{array}{l}12.83 \\
(2.57)\end{array}$ & $\begin{array}{l}14.23 \\
(0.90)\end{array}$ & $\begin{array}{l}13.69 \\
(1.35)\end{array}$ & $\begin{array}{l}20.44 \\
(1.72)\end{array}$ & $\begin{array}{l}23.14 \\
(1.43)\end{array}$ & $\begin{array}{l}24.69 \\
(1.50)\end{array}$ & $\begin{array}{l}23.68 \\
(1.88)\end{array}$ \\
\hline 6 & $\begin{array}{l}16.86 \\
(1.46)\end{array}$ & $\begin{array}{l}15.01 \\
(1.57)\end{array}$ & $\begin{array}{l}17.59 \\
(1.44)\end{array}$ & $\begin{array}{l}15.87 \\
(2.26)\end{array}$ & $\begin{array}{l}16.90 \\
(7.06)\end{array}$ & $\begin{array}{l}15.52 \\
(2.27)\end{array}$ & $\begin{array}{l}15.87 \\
(1.09)\end{array}$ & $\begin{array}{l}14.10 \\
(2.07)\end{array}$ & $\begin{array}{l}16.54 \\
(2.25)\end{array}$ & $\begin{array}{l}17.65 \\
(2.02)\end{array}$ & $\begin{array}{l}18.96 \\
(1.39)\end{array}$ & $\begin{array}{l}26.08 \\
(2.16)\end{array}$ \\
\hline 7 & $\begin{array}{l}19.87 \\
(2.11) \\
\end{array}$ & $\begin{array}{l}18.77 \\
(3.60) \\
\end{array}$ & $\begin{array}{l}19.04 \\
(2.15) \\
\end{array}$ & $\begin{array}{l}19.46 \\
(2.67) \\
\end{array}$ & $\begin{array}{l}11.26 \\
(0.69) \\
\end{array}$ & $\begin{array}{l}10.80 \\
(0.95) \\
\end{array}$ & $\begin{array}{l}12.64 \\
(1.39) \\
\end{array}$ & $\begin{array}{l}13.41 \\
(2.76) \\
\end{array}$ & $\begin{array}{l}19.87 \\
(2.11) \\
\end{array}$ & $\begin{array}{l}18.77 \\
(3.60) \\
\end{array}$ & $\begin{array}{l}19.04 \\
(2.15) \\
\end{array}$ & $\begin{array}{l}19.46 \\
(2.67) \\
\end{array}$ \\
\hline 8 & $\begin{array}{l}21.62 \\
(3.29)\end{array}$ & $\begin{array}{l}22.22 \\
(2.88)\end{array}$ & $\begin{array}{l}21.16 \\
(1.12)\end{array}$ & $\begin{array}{l}21.38 \\
(3.07)\end{array}$ & $\begin{array}{l}15.97 \\
(1.95)\end{array}$ & $\begin{array}{l}15.76 \\
(2.35)\end{array}$ & $\begin{array}{l}17.05 \\
(0.97)\end{array}$ & $\begin{array}{l}16.87 \\
(2.93)\end{array}$ & $\begin{array}{l}20.21 \\
(0.93)\end{array}$ & $\begin{array}{l}23.22 \\
(1.54)\end{array}$ & $\begin{array}{l}24.62 \\
(1.81)\end{array}$ & $\begin{array}{l}25.06 \\
(3.11)\end{array}$ \\
\hline 9 & $\begin{array}{l}14.10 \\
(2.42)\end{array}$ & $\begin{array}{l}10.78 \\
(1.59)\end{array}$ & $\begin{array}{l}14.20 \\
(2.14)\end{array}$ & $\begin{array}{l}14.04 \\
(2.13)\end{array}$ & $\begin{array}{l}12.16 \\
(1.22)\end{array}$ & $\begin{array}{l}12.42 \\
(1.32)\end{array}$ & $\begin{array}{l}12.78 \\
(1.52)\end{array}$ & $\begin{array}{l}12.68 \\
(1.47)\end{array}$ & $\begin{array}{l}14.10 \\
(2.43)\end{array}$ & $\begin{array}{l}10.78 \\
(1.59)\end{array}$ & $\begin{array}{l}14.20 \\
(2.14)\end{array}$ & $\begin{array}{l}14.04 \\
(2.13)\end{array}$ \\
\hline 10 & $\begin{array}{l}14.11 \\
(1.14)\end{array}$ & $\begin{array}{l}11.83 \\
(1.39)\end{array}$ & $\begin{array}{l}19.14 \\
(2.08)\end{array}$ & $\begin{array}{l}16.05 \\
(1.74)\end{array}$ & $\begin{array}{l}13.62 \\
(1.11)\end{array}$ & $\begin{array}{l}11.49 \\
(0.83)\end{array}$ & $\begin{array}{l}14.83 \\
(1.42)\end{array}$ & $\begin{array}{l}11.88 \\
(1.02)\end{array}$ & $\begin{array}{l}14.11 \\
(1.14)\end{array}$ & $\begin{array}{l}11.83 \\
(1.39)\end{array}$ & $\begin{array}{l}19.14 \\
(2.08)\end{array}$ & $\begin{array}{l}16.05 \\
(1.74)\end{array}$ \\
\hline
\end{tabular}


Table A1. Cont.

\begin{tabular}{|c|c|c|c|c|c|c|c|c|c|c|c|c|}
\hline \multirow{3}{*}{$\begin{array}{c}\begin{array}{c}\text { Feedstock Moisture } \\
\text { Content }(\%)\end{array} \\
\text { Compressive Force }(\mathrm{N}) \\
\text { Temperature }\left({ }^{\circ} \mathrm{C}\right)\end{array}$} & \multicolumn{4}{|c|}{12} & \multicolumn{4}{|c|}{15} & \multicolumn{4}{|c|}{ As Received } \\
\hline & \multicolumn{2}{|c|}{1500} & \multicolumn{2}{|c|}{2500} & \multicolumn{2}{|c|}{1500} & \multicolumn{2}{|c|}{2500} & \multicolumn{2}{|c|}{1500} & \multicolumn{2}{|c|}{2500} \\
\hline & 100 & 125 & 100 & 125 & 100 & 125 & 100 & 125 & 100 & 125 & 100 & 125 \\
\hline & \multicolumn{12}{|c|}{ Pellet density $\left(\mathrm{kg} \cdot \mathrm{m}^{-3}\right)$} \\
\hline 1 & $\begin{array}{l}1000 \\
(11)\end{array}$ & $\begin{array}{l}1063 \\
(15)\end{array}$ & $\begin{array}{l}1070 \\
(13)\end{array}$ & $\begin{array}{l}1127 \\
(14)\end{array}$ & $\begin{array}{l}904 \\
(20)\end{array}$ & $\begin{array}{l}1023 \\
(28)\end{array}$ & $\begin{array}{l}950 \\
(26)\end{array}$ & $\begin{array}{l}1113 \\
(23)\end{array}$ & $\begin{array}{l}1000 \\
(18)\end{array}$ & $\begin{array}{l}1071 \\
(13)\end{array}$ & $\begin{array}{l}1094 \\
(14)\end{array}$ & $\begin{array}{l}1146 \\
(25)\end{array}$ \\
\hline 2 & $\begin{array}{l}930 \\
(17)\end{array}$ & $\begin{array}{l}990 \\
(20)\end{array}$ & $\begin{array}{l}969 \\
(11)\end{array}$ & $\begin{array}{l}1023 \\
(32)\end{array}$ & $\begin{array}{l}978 \\
(20)\end{array}$ & $\begin{array}{l}1027 \\
(13)\end{array}$ & $\begin{array}{l}1028 \\
(14)\end{array}$ & $\begin{array}{c}1042 \\
(26)\end{array}$ & $\begin{array}{l}936 \\
(35)\end{array}$ & $\begin{array}{l}990 \\
(30)\end{array}$ & $\begin{array}{l}968 \\
(18)\end{array}$ & $\begin{array}{c}1022 \\
(43)\end{array}$ \\
\hline 3 & $\begin{array}{c}1012 \\
(16)\end{array}$ & $\begin{array}{c}1034 \\
(15)\end{array}$ & $\begin{array}{c}1070 \\
(17)\end{array}$ & $\begin{array}{c}1098 \\
(13)\end{array}$ & $\begin{array}{l}991 \\
(15)\end{array}$ & $\begin{array}{c}1062 \\
(14)\end{array}$ & $\begin{array}{c}1049 \\
(11)\end{array}$ & $\begin{array}{c}1143 \\
(9)\end{array}$ & $\begin{array}{c}1012 \\
(16)\end{array}$ & $\begin{array}{c}1034 \\
(15)\end{array}$ & $\begin{array}{c}1070 \\
(17)\end{array}$ & $\begin{array}{c}1098 \\
(13)\end{array}$ \\
\hline 4 & $\begin{array}{l}1032 \\
(16)\end{array}$ & $\begin{array}{l}1070 \\
(28)\end{array}$ & $\begin{array}{c}1102 \\
(9)\end{array}$ & $\begin{array}{l}1132 \\
(23)\end{array}$ & $\begin{array}{l}938 \\
(52)\end{array}$ & $\begin{array}{l}1018 \\
(27)\end{array}$ & $\begin{array}{l}963 \\
(15)\end{array}$ & $\begin{array}{l}1037 \\
(43)\end{array}$ & $\begin{array}{c}1032 \\
(16)\end{array}$ & $\begin{array}{l}1070 \\
(12)\end{array}$ & $\begin{array}{c}1108 \\
(11)\end{array}$ & $\begin{array}{l}1154 \\
(13)\end{array}$ \\
\hline 5 & $\begin{array}{l}1033 \\
(19)\end{array}$ & $\begin{array}{c}1079 \\
(7)\end{array}$ & $\begin{array}{l}1119 \\
(15)\end{array}$ & $\begin{array}{l}1125 \\
(51)\end{array}$ & $\begin{array}{l}966 \\
(40) \\
\end{array}$ & $\begin{array}{l}1012 \\
(42)\end{array}$ & $\begin{array}{r}981 \\
(17) \\
\end{array}$ & $\begin{array}{l}1007 \\
(40)\end{array}$ & $\begin{array}{c}1030 \\
(9)\end{array}$ & $\begin{array}{l}1100 \\
(10)\end{array}$ & $\begin{array}{c}1126 \\
(9)\end{array}$ & $\begin{array}{l}1151 \\
(39)\end{array}$ \\
\hline 6 & $\begin{array}{l}1056 \\
(10)\end{array}$ & $\begin{array}{l}1079 \\
(23)\end{array}$ & $\begin{array}{c}1114 \\
(9)\end{array}$ & $\begin{array}{l}1148 \\
(44)\end{array}$ & $\begin{array}{l}1195 \\
(513)\end{array}$ & $\begin{array}{l}1032 \\
(49)\end{array}$ & $\begin{array}{l}1010 \\
(18)\end{array}$ & $\begin{array}{c}1064 \\
(45)\end{array}$ & $\begin{array}{l}1070 \\
(14)\end{array}$ & $\begin{array}{l}1077 \\
(17)\end{array}$ & $\begin{array}{l}1147 \\
(12)\end{array}$ & $\begin{array}{l}1162 \\
(13)\end{array}$ \\
\hline 7 & $\begin{array}{l}1097 \\
(24)\end{array}$ & $\begin{array}{l}1104 \\
(20)\end{array}$ & $\begin{array}{l}1147 \\
(15)\end{array}$ & $\begin{array}{l}1146 \\
(33)\end{array}$ & $\begin{array}{l}1005 \\
(14)\end{array}$ & $\begin{array}{c}1042 \\
(35)\end{array}$ & $\begin{array}{c}1034 \\
(10)\end{array}$ & $\begin{array}{c}1085 \\
(47)\end{array}$ & $\begin{array}{l}1097 \\
(24)\end{array}$ & $\begin{array}{l}1104 \\
(20)\end{array}$ & $\begin{array}{l}1147 \\
(15)\end{array}$ & $\begin{array}{l}1146 \\
(33)\end{array}$ \\
\hline 8 & $\begin{array}{l}1092 \\
(44)\end{array}$ & $\begin{array}{c}1125 \\
(9)\end{array}$ & $\begin{array}{l}1167 \\
(14)\end{array}$ & $\begin{array}{l}1149 \\
(34)\end{array}$ & $\begin{array}{l}997 \\
(17)\end{array}$ & $\begin{array}{l}1050 \\
(43)\end{array}$ & $\begin{array}{l}1037 \\
(20)\end{array}$ & $\begin{array}{c}1089 \\
(69)\end{array}$ & $\begin{array}{l}1078 \\
(14)\end{array}$ & $\begin{array}{l}1091 \\
(23)\end{array}$ & $\begin{array}{c}1168 \\
(16)\end{array}$ & $\begin{array}{l}1180 \\
(29)\end{array}$ \\
\hline 9 & $\begin{array}{l}1057 \\
(20)\end{array}$ & $\begin{array}{c}1094 \\
(6)\end{array}$ & $\begin{array}{l}1121 \\
(27)\end{array}$ & $\begin{array}{l}1138 \\
(16)\end{array}$ & $\begin{array}{l}991 \\
(26)\end{array}$ & $\begin{array}{c}1030 \\
(37)\end{array}$ & $\begin{array}{c}1022 \\
(41)\end{array}$ & $\begin{array}{c}1035 \\
(32)\end{array}$ & $\begin{array}{l}1057 \\
(20)\end{array}$ & $\begin{array}{c}1094 \\
(6)\end{array}$ & $\begin{array}{l}1121 \\
(27)\end{array}$ & $\begin{array}{l}1138 \\
(16)\end{array}$ \\
\hline \multirow[t]{2}{*}{10} & $\begin{array}{l}1064 \\
(30)\end{array}$ & $\begin{array}{c}1096 \\
(5)\end{array}$ & $\begin{array}{l}1127 \\
(12)\end{array}$ & $\begin{array}{l}1172 \\
(26)\end{array}$ & $\begin{array}{l}985 \\
(12)\end{array}$ & $\begin{array}{l}1002 \\
(15)\end{array}$ & $\begin{array}{l}1007 \\
(18)\end{array}$ & $\begin{array}{c}1020 \\
(14)\end{array}$ & $\begin{array}{l}1064 \\
(18)\end{array}$ & $\begin{array}{l}1096 \\
(13)\end{array}$ & $\begin{array}{l}1127 \\
(14)\end{array}$ & $\begin{array}{l}1172 \\
(25)\end{array}$ \\
\hline & \multicolumn{12}{|c|}{ Pellet strength $\left(\mathrm{N} \cdot \mathrm{mm}^{-1}\right)$} \\
\hline 1 & $\begin{array}{l}33.30 \\
(2.18)\end{array}$ & $\begin{array}{l}53.39 \\
(3.51)\end{array}$ & $\begin{array}{l}40.82 \\
(1.94)\end{array}$ & $\begin{array}{l}62.43 \\
(2.69)\end{array}$ & $\begin{array}{l}24.78 \\
(1.34)\end{array}$ & $\begin{array}{l}39.99 \\
(6.77)\end{array}$ & $\begin{array}{l}26.20 \\
(7.28)\end{array}$ & $\begin{array}{l}42.48 \\
(26.62)\end{array}$ & $\begin{array}{l}31.36 \\
(3.18)\end{array}$ & $\begin{array}{l}54.67 \\
(1.50)\end{array}$ & $\begin{array}{l}43.72 \\
(4.96)\end{array}$ & $\begin{array}{l}61.33 \\
(5.85)\end{array}$ \\
\hline 2 & $\begin{array}{l}38.84 \\
(3.73)\end{array}$ & $\begin{array}{l}40.51 \\
(5.56)\end{array}$ & $\begin{array}{l}29.46 \\
(1.06)\end{array}$ & $\begin{array}{l}39.35 \\
(2.73)\end{array}$ & $\begin{array}{l}35.30 \\
(5.45)\end{array}$ & $\begin{array}{l}53.05 \\
(6.13)\end{array}$ & $\begin{array}{l}42.15 \\
(3.42)\end{array}$ & $\begin{array}{l}39.81 \\
(3.30)\end{array}$ & $\begin{array}{l}36.43 \\
(1.15)\end{array}$ & $\begin{array}{l}39.42 \\
(5.08)\end{array}$ & $\begin{array}{l}35.72 \\
(9.18)\end{array}$ & $\begin{array}{l}36.75 \\
(5.64)\end{array}$ \\
\hline 3 & $\begin{array}{l}39.63 \\
(2.54)\end{array}$ & $\begin{array}{l}44.96 \\
(6.49)\end{array}$ & $\begin{array}{l}44.00 \\
(4.25)\end{array}$ & $\begin{array}{l}48.25 \\
(1.51)\end{array}$ & $\begin{array}{l}39.80 \\
(9.28)\end{array}$ & $\begin{array}{l}48.63 \\
(2.11)\end{array}$ & $\begin{array}{l}39.86 \\
(3.35)\end{array}$ & $\begin{array}{l}58.94 \\
(1.57)\end{array}$ & $\begin{array}{l}39.63 \\
(2.54)\end{array}$ & $\begin{array}{l}44.96 \\
(6.49)\end{array}$ & $\begin{array}{l}44.00 \\
(4.25)\end{array}$ & $\begin{array}{l}48.25 \\
(1.51)\end{array}$ \\
\hline 4 & $\begin{array}{l}34.88 \\
(4.24)\end{array}$ & $\begin{array}{l}54.15 \\
(11.28)\end{array}$ & $\begin{array}{l}45.06 \\
(6.38)\end{array}$ & $\begin{array}{l}55.21 \\
(7.59)\end{array}$ & $\begin{array}{l}28.00 \\
(7.36)\end{array}$ & $\begin{array}{l}36.58 \\
(5.00)\end{array}$ & $\begin{array}{l}28.63 \\
(2.05)\end{array}$ & $\begin{array}{l}45.84 \\
(4.66)\end{array}$ & $\begin{array}{l}35.44 \\
(1.68)\end{array}$ & $\begin{array}{l}50.72 \\
(3.05)\end{array}$ & $\begin{array}{l}45.41 \\
(4.04)\end{array}$ & $\begin{array}{l}64.20 \\
(3.88)\end{array}$ \\
\hline 5 & $\begin{array}{l}43.97 \\
(1.93)\end{array}$ & $\begin{array}{l}60.68 \\
(1.75)\end{array}$ & $\begin{array}{l}55.43 \\
(3.67)\end{array}$ & $\begin{array}{l}77.07 \\
(4.91)\end{array}$ & $\begin{array}{l}33.38 \\
(8.05)\end{array}$ & $\begin{array}{l}47.08 \\
(10.90)\end{array}$ & $\begin{array}{l}38.81 \\
(1.00)\end{array}$ & $\begin{array}{l}45.35 \\
(9.48)\end{array}$ & $\begin{array}{l}44.55 \\
(2.00)\end{array}$ & $\begin{array}{l}65.31 \\
(3.77) \\
\end{array}$ & $\begin{array}{l}63.35 \\
(2.91) \\
\end{array}$ & $\begin{array}{l}80.54 \\
(6.23) \\
\end{array}$ \\
\hline 6 & $\begin{array}{l}41.43 \\
(1.41)\end{array}$ & $\begin{array}{l}52.59 \\
(7.85)\end{array}$ & $\begin{array}{l}49.37 \\
(1.32)\end{array}$ & $\begin{array}{l}44.68 \\
(29.15)\end{array}$ & $\begin{array}{l}32.55 \\
(1.87)\end{array}$ & $\begin{array}{l}50.59 \\
(5.72)\end{array}$ & $\begin{array}{l}33.08 \\
(4.60)\end{array}$ & $\begin{array}{l}53.30 \\
(8.87)\end{array}$ & $\begin{array}{l}35.93 \\
(1.42)\end{array}$ & $\begin{array}{l}48.05 \\
(8.34)\end{array}$ & $\begin{array}{l}50.65 \\
(4.15)\end{array}$ & $\begin{array}{l}55.72 \\
(10.49)\end{array}$ \\
\hline 7 & $\begin{array}{l}65.49 \\
(3.42)\end{array}$ & $\begin{array}{l}69.02 \\
(7.49)\end{array}$ & $\begin{array}{l}67.00 \\
(3.82)\end{array}$ & $\begin{array}{l}81.46 \\
(2.28)\end{array}$ & $\begin{array}{l}42.61 \\
(1.96)\end{array}$ & $\begin{array}{l}60.16 \\
(90.50)\end{array}$ & $\begin{array}{l}45.96 \\
(1.48)\end{array}$ & $\begin{array}{l}62.24 \\
(6.62)\end{array}$ & $\begin{array}{l}65.49 \\
(3.42)\end{array}$ & $\begin{array}{l}69.02 \\
(7.49)\end{array}$ & $\begin{array}{l}67.00 \\
(3.82)\end{array}$ & $\begin{array}{l}81.46 \\
(2.28)\end{array}$ \\
\hline 8 & $\begin{array}{l}53.89 \\
(13.24)\end{array}$ & $\begin{array}{l}71.00 \\
(8.30)\end{array}$ & $\begin{array}{l}74.34 \\
(6.26)\end{array}$ & $\begin{array}{l}86.88 \\
(1.50)\end{array}$ & $\begin{array}{l}38.78 \\
(2.23)\end{array}$ & $\begin{array}{l}65.77 \\
(9.26)\end{array}$ & $\begin{array}{l}43.31 \\
(6.87)\end{array}$ & $\begin{array}{l}66.73 \\
(16.80)\end{array}$ & $\begin{array}{l}53.37 \\
(4.28)\end{array}$ & $\begin{array}{l}65.97 \\
(6.49)\end{array}$ & $\begin{array}{l}74.07 \\
(3.61)\end{array}$ & $\begin{array}{l}80.54 \\
(12.06)\end{array}$ \\
\hline 9 & $\begin{array}{l}44.85 \\
(2.14)\end{array}$ & $\begin{array}{l}53.06 \\
(3.76)\end{array}$ & $\begin{array}{l}49.70 \\
(2.12)\end{array}$ & $\begin{array}{l}56.76 \\
(4.29)\end{array}$ & $\begin{array}{l}32.46 \\
(4.73)\end{array}$ & $\begin{array}{l}43.55 \\
(7.40)\end{array}$ & $\begin{array}{l}34.27 \\
(4.05)\end{array}$ & $\begin{array}{l}38.24 \\
(5.61)\end{array}$ & $\begin{array}{l}44.85 \\
(2.14)\end{array}$ & $\begin{array}{l}53.06 \\
(3.76)\end{array}$ & $\begin{array}{l}49.70 \\
(2.12)\end{array}$ & $\begin{array}{l}56.76 \\
(4.29)\end{array}$ \\
\hline 10 & $\begin{array}{l}43.32 \\
(13.37)\end{array}$ & $\begin{array}{l}59.53 \\
(4.85)\end{array}$ & $\begin{array}{l}60.98 \\
(3.31)\end{array}$ & $\begin{array}{l}76.35 \\
(4.86)\end{array}$ & $\begin{array}{l}37.78 \\
(2.58)\end{array}$ & $\begin{array}{l}47.31 \\
(6.89)\end{array}$ & $\begin{array}{l}42.81 \\
(2.74)\end{array}$ & $\begin{array}{l}43.87 \\
(3.47)\end{array}$ & $\begin{array}{l}43.32 \\
(13.37)\end{array}$ & $\begin{array}{l}59.53 \\
(4.85)\end{array}$ & $\begin{array}{l}60.98 \\
(3.31)\end{array}$ & $\begin{array}{l}76.35 \\
(4.86)\end{array}$ \\
\hline
\end{tabular}

\section{References}

1. Chum, H.; Faaij, A.; Moreira, J.; Berndes, G.; Dhamija, P.; Dong, H.; Gabrielle, B.; Goss Eng, A.; Lucht, W.; Mapako, M.; et al. Bioenergy. In IPCC Special Report on Renewable Energy Sources and Climate Change Mitigation; Edenhofer, O., Pichs-Madruga, R., Sokona, Y., Seyboth, K., Matschoss, P., Kadner, S., Zwickel, T., Eickemeier, P., Hansen, G., Schlömer, S., et al., Eds.; Cambridge University Press: Cambridge, UK, 2011.

2. Kopetz, H. Build a biomass energy market. Nature 2013, 494, 29. [CrossRef] [PubMed] 
3. Majer, S.; Thrän, D. Biomass Resources and Sustainability Issues for a Flexible Bioenergy Provision. In Smart Bioenergy: Technologies and Concepts for a More Flexible Bioenergy Provision in Future Energy Systems; Thrän, D., Ed.; Springer International Publishing: Cham, Switzerland, 2015; pp. 33-48. [CrossRef]

4. Lamers, P.; Hoefnagels, R.; Junginger, M.; Hamelinck, C.; Faaij, A. Global solid biomass trade for energy by 2020: An assessment of potential import streams and supply costs to North-West Europe under different sustainability constraints. GCB Bioenergy 2015, 7, 618-634. [CrossRef]

5. Sultana, A.; Kumar, A. Ranking of biomass pellets by integration of economic, environmental and technical factors. Biomass Bioenergy 2012, 39, 344-355. [CrossRef]

6. Thrän, D.; Peetz, D.; Schaubach, K. Global Wood Pellet Industry and Trade Study 2017. Available online: http://task40.ieabioenergy.com/wp-content/uploads/2013/09/IEA-Wood-Pellet-Study_final-2017-06.pdf (accessed on 23 July 2019).

7. Gouvernement du Québec. Production et Utilisation des Sous-Produits Générés par les Entreprises de Deuxième Transformation du Bois du Québec en 2013; Ministère des Forêts, de la Faune et des Parcs, Ed.; Gouvernement du Québec: Quebec City, QC, Canada, 2014; p. 36.

8. Ghafghazi, S.; Lochhead, K.; Mathey, A.-H.; Forsell, N.; Leduc, S.; Mabee, W.; Bull, G. Estimating mill residue surplus in Canada: A spatial forest fiber cascade modeling approach. For. Prod. J. 2017, 67, 205-218. [CrossRef]

9. Bradfield, J.; Levi, M. Effect of species and wood to bark ratio on pelleting of southern woods. For. Prod. J. 1984, 34, 61-63.

10. Holm, J.K.; Henriksen, U.B.; Hustad, J.E.; Sørensen, L.H. Toward an Understanding of Controlling Parameters in Softwood and Hardwood Pellets Production. Energy Fuel 2006, 20, 2686-2694. [CrossRef]

11. Nguyen, Q.N.; Cloutier, A.; Achim, A.; Stevanovic, T. Effect of process parameters and raw material characteristics on physical and mechanical properties of wood pellets made from sugar maple particles. Biomass Bioenergy 2015, 80, 338-349. [CrossRef]

12. Obernberger, I.; Thek, G. The Pellet Handbook: The Production and Thermal Utilisation of Pellets; Earthscan: London, UK, 2010; p. 592.

13. Arshadi, M.; Gref, R.; Geladi, P.; Dahlqvist, S.-A.; Lestander, T. The influence of raw material characteristics on the industrial pelletizing process and pellet quality. Fuel Process. Technol. 2008, 89, 1442-1447. [CrossRef]

14. Junginger, M.; van Dam, J.; Zarrilli, S.; Ali Mohamed, F.; Marchal, D.; Faaij, A. Opportunities and barriers for international bioenergy trade. Energy Policy 2011, 39, 2028-2042. [CrossRef]

15. Goh, C.S.; Junginger, M.; Cocchi, M.; Marchal, D.; Thrän, D.; Hennig, C.; Heinimö, J.; Nikolaisen, L.; Schouwenberg, P.-P.; Bradley, D.; et al. Wood pellet market and trade: A global perspective. Biofuel. Bioprod. Biorefin. 2013, 7, 24-42. [CrossRef]

16. BSI. DD CEN/TS 15149-1:2006 Solid Biofuels. Methods for the Determination of Particle Size Distribution. Oscillating Screen Method Using Sieve Apertures of 3,15 mm and Above; BSI: London, UK, 2006.

17. BSI. DD CEN/TS 15149-2:2006 Solid Biofuels. Methods for the Determination of Particle Size Distribution. Vibrating Screen Method Using Sieve Apertures of 3,15 mm and Below; BSI: London, UK, 2006.

18. Barrette, J.; Pothier, D.; Duchesne, I. Lumber and wood chips properties of dead and sound black spruce trees grown in the boreal forest of Canada. For. Int. J. For. Res. 2015, 88, 108-120. [CrossRef]

19. European Committee for Standardization. EN ISO 18134-3:2015. Solid Biofuels. Determination of Moisture Content. Oven Dry Method. Moisture in General Analysis Sample; European Committee for Standardization: Brussels, Belgium, 2015.

20. ASTM International. ASTM D5057-10 (2010) Standard Test Method for Screening Apparent Specific Gravity and Bulk Density of Waste; ASTM International: West Conshohocken, PA, USA, 2010.

21. European Committee for Standardization. EN ISO 18125:2017. Solid Biofuels. Determination of Calorific Value; European Committee for Standardization: Brussels, Belgium, 2017.

22. Van Soest, P.J.; Robertson, J.B.; Lewis, B.A. Methods for Dietary Fiber, Neutral Detergent Fiber, and Nonstarch Polysaccharides in Relation to Animal Nutrition. J. Dairy Sci. 1991, 74, 3583-3597. [CrossRef]

23. Godin, B.; Agneessens, R.; Gofflot, S.; Lamaudière, S.; Sinnaeve, G.; Gerin, P.A.; Delcarte, J. Revue bibliographique sur les méthodes d'analyse des polysaccharides structuraux des biomasses lignocellulosiques/Review on analytical methods for lignocellulosic biomass structural polysaccharides. Biotechnol. Agron. Société Environ. 2011, 15, 165. 
24. ASTM International. ASTM D1102-84(2013), Standard Test Method for Ash in Wood; ASTM International: West Conshohocken, PA, USA, 2013.

25. Team, R.C. R: A Language and Environment for Statistical Computing, v. 3.0.1; R Foundation for Statistical Computing: Vienna, Austria, 2013.

26. Coronella, C.J.; Yan, W.; Reza, M.T.; Vasquez, V.R. Method for Wet Torrefacton of Biomass. US Patent App. 13/223,562, 10 May 2012.

27. Bhattacharya, S.C.; Sett, S.; Shrestha, R.M. State of the Art for Biomass Densification. Energy Sour. 1989, 11, 161-182. [CrossRef]

28. Hansen, M.T.; Jein, A.R.; Hayes, S.; Bateman, P. English Handbook for Wood Pellet Combustion; National Energy Foundation: Milton Keynes, UK, 2009; p. 85.

29. Tillman, D.A. Wood as an Energy Resource; Academic Press: New York, NY, USA, 1978; p. 266.

30. Panshin, A.J.; Zeeuw, C.D. Textbook of Wood Technology; McGraw-Hill Book Co.: New York, NY, USA, 1980; p. 772.

31. Telmo, C.; Lousada, J. Heating values of wood pellets from different species. Biomass Bioenergy 2011, 35, 2634-2639. [CrossRef]

32. Demirbas, A. Relationships between Heating Value and Lignin, Moisture, Ash and Extractive Contents of Biomass Fuels. Energy Explor. Exploit. 2002, 20, 105-111. [CrossRef]

33. Kataki, R.; Konwer, D. Fuelwood characteristics of some indigenous woody species of north-east India. Biomass Bioenergy 2001, 20, 17-23. [CrossRef]

34. Alakangas, E.; Valtanen, J.; Levlin, J.-E. CEN technical specification for solid biofuels-Fuel specification and classes. Biomass Bioenergy 2006, 30, 908-914. [CrossRef]

35. Obernberger, I.; Brunner, T.; Bärnthaler, G. Chemical properties of solid biofuels-Significance and impact. Biomass Bioenergy 2006, 30, 973-982. [CrossRef]

36. Werther, J.; Saenger, M.; Hartge, E.-U.; Ogada, T.; Siagi, Z. Combustion of agricultural residues. Prog. Energy Combust. Sci. 2000, 26, 1-27. [CrossRef]

37. Tarasov, D.; Shahi, C.; Leitch, M. Effect of additives on wood pellet physical and thermal characteristics: A review. Isrn For. 2013, 1-6. [CrossRef]

38. Telmo, C.; Lousada, J.; Moreira, N. Proximate analysis, backwards stepwise regression between gross calorific value, ultimate and chemical analysis of wood. Bioresour. Technol. 2010, 101, 3808-3815. [CrossRef] [PubMed]

39. Leckner, B.; Karlsson, M. Gaseous emissions from circulating fluidized bed combustion of wood. Biomass Bioenergy 1993, 4, 379-389. [CrossRef]

40. Shang, L.; Nielsen, N.P.K.; Stelte, W.; Dahl, J.; Ahrenfeldt, J.; Holm, J.K.; Arnavat, M.P.; Bach, L.S.; Henriksen, U.B. Lab and bench-scale pelletization of torrefied wood chips-Process optimization and pellet quality. BioEnergy Res. 2014, 7, 87-94. [CrossRef]

41. Kuang, X.; Shankar, T.J.; Bi, X.T.; Lim, C.J.; Sokhansanj, S.; Melin, S. Rate and peak concentrations of off-gas emissions in stored wood pellets-Sensitivities to temperature, relative humidity, and headspace volume. Anna. Occup. Hyg. 2009, 53, 789-796.

42. Stelte, W.; Holm, J.K.; Sanadi, A.R.; Barsberg, S.; Ahrenfeldt, J.; Henriksen, U.B. Fuel pellets from biomass: The importance of the pelletizing pressure and its dependency on the processing conditions. Fuel 2011, 90, 3285-3290. [CrossRef]

43. Asikainen, A.; Ikonen, T.; Routa, J. Challenges and opportunities of logistics and economics of forest biomass. In Mobilisation of Forest Bioenergy in the Boreal and Temperate Biomes: Challenges, Opportunities and Case Studies; Thiffault, E., Berndes, G., Junginger, M., Saddler, J., Smith, T., Eds.; Academic Press: Cambridge, MA, USA, 2016; pp. 68-83.

44. Kong, J.; Rönnqvist, M.; Frisk, M. Modeling an integrated market for sawlogs, pulpwood, and forest bioenergy. Can. J. For. Res. 2012, 42, 315-332. [CrossRef]

(C) 2019 by the authors. Licensee MDPI, Basel, Switzerland. This article is an open access article distributed under the terms and conditions of the Creative Commons Attribution (CC BY) license (http://creativecommons.org/licenses/by/4.0/). 